\title{
ĀGENSKALNA VINGROŠANAS UN SPORTA BIEDRĪBAS DARBĪBA UN NAMS BALDONES IELĀ 7
}

\author{
RITA APINE* \\ Latvijas Sporta muzejs
}

Kopsavilkums. Āgenskalna Vingrošanas un sporta biedrība bija viena no lielākajām un pazīstamākajām vācbaltiešu sporta organizācijām 20. gadsimta pirmajā pusē. Tajā darbojušies dažādu profesiju sporta entuziasti, tostarp inženieri. Sporta dzīvē nozīmīgs bija biedrības 1910. gadā uzceltais nams Rīgā, Baldones ielā 7, kas līdz mūsdienām vairākkārt pārbūvēts. Pētījumā rodams bagātīgs materiāls par biedrību un tās namu līdz vācbaltiešu izceḷošanai 1939. gadā. Izmantojot Latvijas Nacionālā arhīva Latvijas Valsts vēstures arhīva (LNA LVVA) dokumentus un preses materiālus, Rīgas Būvvaldes arhīva dokumentus, kā arī Latvijas Sporta muzeja krājumu, atklāti agrāk nezināmi fakti.

Atslēgas vārdi: Āgenskalna Vingrošanas un sporta biedrība, Baldones iela 7, arhitekti Leopolds Rīmers, Haralds Blaus, Alfrēds Laukirbe.

\section{Ievads}

Kurzemes un Vidzemes guberṇās, kas tolaik bija cariskās Krievijas sastāvā, sports mūsdienu izpratnē uzplauka 19. gadsimta otrajā pusē [1]. Te bija pazīstami visi tie sporta veidi, kādus pazina Skandināvijā un Rietumeiropā. No 19. gadsimta vidus līdz pat Pirmajam pasaules karam Baltijas guberñās darbojās ap 160 sporta organizāciju, Latvijas teritorijā - vairāk nekā 90 .

Sporta dzīves veidošanās pirmsākumus Baltijas guberṇās noteica vācu muižniecības tradīcijas un vācbaltiešu mentalitāte. Vācu kultūras labvēlīgā iespaidā 19. gadsimta trīsdesmitajos gados aizsākās vingrošanas jeb ǵimnastikas kustība, kas Rietumeiropu pāršalca 18. un 19. gadsimta mijā. Sporta biedrībās radās interese par vingrošanu un tās ieviešanu skolās rotaļu un fizisku vingrinājumu veidā.

* Korespondējošais autors.

E-pasts: rita.apine@sportamuzejs.lv

(C) 2021 Rita Apine. Izdevējs RTU Izdevniecība.

Raksts publicēts brīvpieejā saskaṇā ar Creative Commons licenci CC BY 4.0.

(https://creativecommons.org/licenses/by/4.0/). 
Pirmie sporta pionieri Latvijā bija vācbaltieši, kuri bija izglītojušies vācu skolās un sporta institūtos, vēlāk nonākot Baltijas guberñās.

Par vingrošanas centriem Baltijā 19. gadsimtā izveidojās jaundibinātās vingrošanas biedrības Rēvelē (dib. 1819; tagad - Tallina), Rīgā (1862), Tērbatā (1864; tagad - Tartu), Liepājā (1885).

1862. gada pavasarī vācietis Vilhelms Vārbands (Wilhelm Wahrbandt; 1837-1894) kopā ar domubiedriem nodibināja pirmo vingrošanas biedrību Latvijā - Rīgas Vingrošanas biedrību (RVB; Rigaer Turnverein), kurā darbojās arī Rīgas Politehnikuma (RP), no 1896. gada - Rīgas Politehniskā institūta (RPI), studenti un mācībspēki.

1881. gadā pēc Rīgas pilsētas arhitekta (1879-1915) Reinholda Šmēlinga (Reinhold Schmaehling; 1840-1917) projekta uzbūvēja itāḷu renesanses stila mūra celtni ar modernu vingrošanas zāli blakus Rīgas pilsētas reālskolai Nikolaja bulvārī (tagad - K. Valdemāra iela) [2].

Iedvesmojoties no RVB, domubiedru mudināti, vācbaltieši 20. gadsimta sākumā aizsāka vingrošanas kustību Daugavas kreisajā krastā - Āgenskalnā un tās apkaimē. Sporta dzīve veidojās un attīstījās, pateicoties četrām spēcīgām vācbaltiešu sporta organizācijām - Āgenskalna Slidkalna (mūsdienu izpratnē - slidkalniṇa) biedrībai (dib. 1896; Hagensberger Rodelverein), Āgenskalna Vingrošanas un sporta biedrībai (ĀVSB; 1903; Hagensberger Turn- und Sport-verein), Āgenskalna Strēlnieku biedrībai (1907; Hagensberger Schuetzengesellschaft zu Riga) un Āgenskalna Saviesīgajai biedrībai (1896; Hagensberger Geselliger Verein).

Pētījuma mērksis - izpētīt vācu Āgenskalna Vingrošanas un sporta biedrības darbību un inženieru lomu tajā, biedrības nama tapšanas vēsturi un arhitektu līdzdalību tā izveidē, kā arī izvērtēt biedrības darbības nozīmi Latvijas sporta attīstībā 20. gadsimta sākumā un Latvijas Republikā (1918-1940). Pētījums veikts, izmantojot hermeneitikas, avotu un literatūras pētīšanas metodes.

\section{Sports Āgenskalnā līdz Pirmajam pasaules karam}

Kopš 1880. gada Āgenskalna parks ar Vasaras teātri Rīgā, Pārdaugavā, toreizējā Jelgavas priekšpilsētā, Kalnciema ielā 11, piederēja Georgam Johanam Ebertam (Georg Johannes Ebert; 1850-1920) [3; 34. lpp.]. Vēl krietni pirms ĀVSB dibināšanas un tās vingrotavas uzbūvēšanas par sabiedrisku vingrošanas punktu izveidojās Eberta restorāns Āgenskalna parkā. Vieta ar lielās koka ēkas plašo zāli, bumbotavu, šautuvi un skaistu dārzu vingrošanai un sportošanai bija loti pievilcīga [4; 55. lpp.]. Vingrošana notika pirmdienu un ceturtdienu vakaros no pulksten aston,iem līdz desmitiem [3; 278. lpp.]. Otrs 
vingrošanas atbalsta punkts bija Āgenskalna Saviesīgās biedrības mītne Baložu ielā 15, kur itin bieži dažādus pasākumus kuplināja arī vingrošanas priekšnesumi. 1903. gada 11. maijā biedrības telpās notika Vingrošanas sekcijas pirmā sapulce [5]. Sekcija bija nolēmusi kḷūt par patstāvīgu biedrību [6] un turpmāk sevi dēvēja par Āgenskalna Vingrošanas un sporta biedrību. Jaunās biedrības Statūti tika apstiprināti 1903. gada 7. novembrī. Biedrības mērḳis bija apvienot cilvēkus, lai mācītu pareizi vingrot, braukt ar velosipēdu, slidot, peldēt, apgūt dažādus sporta veidus un attīstīt sevi. Mērḳa vārdā bija iecerēts ierīkot slēgtas un atklātas vietas, kur varētu ne tikai sportot, bet apgūt arī sporta rīku tehnisko uzbūvi, rīkotu sacensības un ar likumu ațlautus izklaides pasākumus, spēles un rotaḷas, izṇemot kāršu spēles. Statūti noteica, ka izbraukumos un sacensībās biedriem jābūt biedrības formā ar formas tērpa galvassegas atšķirības zīmi - kokardi, uz piedurknes lenti. Sporta biedrības formu apstiprināja vietējais gubernators [7; 15. lp.].

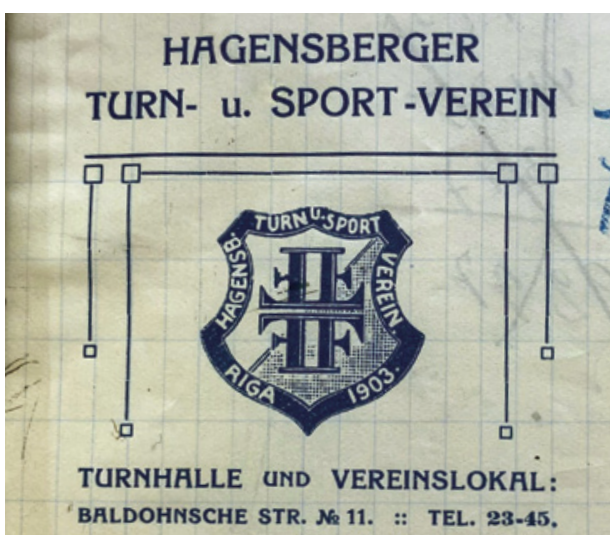

1. attēls. Āgenskalna Vingrošanas un sporta biedrības logo (1918).

ĀVSB devīze un sportiskais sveiciens bija «Labu veiksmi!» («Gut Heill»»), biedrības zīme jeb logo, tāpat kā RVB, ar četru «F» burtu savijumu bija patapināts no Vācijas vingrošanas svētku oficiālās simbolikas, paužot vēlmi pievienoties un būt kopā ar šo moderno un skaitliski iespaidīgo vingrošanas kustību. Burts «F» ir četru vārdu vācu valodā - frisch, fromm, fröhlich, frei (možs, dievbijīgs, līksms, brīvs) pirmais burts, un šie četri vardi ir arī vācu pedagoga, viena no mūsdienu sporta vingrošanas pamatlicējiem Frīdriha Ludviga Jāna (Friedrich Ludwig Jahn; 1778-1852) vingrošanas devīze. Biedrības krāsas bija balta un zila. Vēlāk - jau 20. gadsimta trīsdesmitajos gados - krūšu nozīmītei tika pievienota zelta krāsa [8; 18. lp.]. ĀVSB vadību uzṇēmās ārsts Oskars Zuks (Oskar Suck; 1864-1934), Vingrošanas sekcijas - Johans Žano Štāls (Johann Jeannot Stahl; 1874?-pēc 1937). 


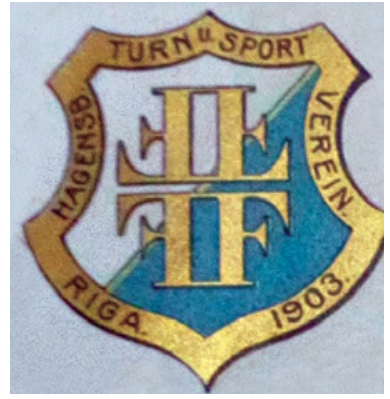

1904. gada 30. maijā ĀVSB kopā ar RVB sarīkoja pirmās oficiālās vingrošanas sacensības Rīgas pilsētas reālskolas vingrošanas laukumā (blakus iespaidīgajam RVB namam) pēc Vācijas vingrošanas biedrību noteikumiem. Sacensību programmā līdzās «klasiskajai» vingrošanai vingrojumiem uz rīkiem (vingrošanas pieccīnna) bija arī hanteḷu cilāšana, augstlēkšana un kārtslēkšana [9].

Āgenskalna Strēlnieku biedrība izveidojās, Šaušanas sekcijai atdaloties no ĀVSB. Tās Statūti tika apstiprināti 1907. gada 3. septembrī [10]. Biedrība izveidojās, vācbaltiešiem baidoties par savu drošību un mantu, jo laiks pēc Krievijas zaudējuma karā ar Japānu 1905. gadā un tam sekojošā 1905. gada revolūcija radīja nepieciešamību pēc organizēšanās un pašaizsardzības. Par sanākšanas vietu kḷuva nams Baložu ielā 15, savukārt šaušanas nodarbībām un sacensībām tika izvēlēts laukums Ventspils ielā 62 un 64 [3; 273. lp.].

Par iedvesmas avotu sacensību rīkošanai kalpoja kopš 1860. gada rīkotie grandiozie vingrošanas svētki Vācijā, kuros viesu statusā 1903., 1908. un 1913. gadā piedalījās arī Rīgas un Kuldīgas vingrotāju biedrību pārstāvji. Vingrošanas svētku apmeklējumi tika plaši atspoguḷoti vācbaltiešu presē, vingrošanas nozares vadītāji un šo svētku viesi uzstājās ar priekšlasījumiem biedrību publiskajos sarīkojumos.

1910. gadā tika izveidota ĀVSB futbola komanda (viena no labākajām Rīgā), kas piedalījās Rīgas futbola līgā, kā arī Rīgas kausa un Rīgas Politehnikuma absolventa Gustava Ādolfa Agtes (Gustav Adolph Agthe; 1850-1906) kausa izcīnā.

1912. gadā ĀVSB bija to 18 Baltijas provinču vācbaltu sporta biedrību vidū, kuru sportisti piedalījās V Stokholmas olimpiādes spēlēs cariskās Krievijas komandas sastāvā. To vidū RPI Arhitektūras nodaḷas students Haralds Blaus (1885-1945), kurš ieguva bronzas medalı šaušanā. Tās bija pirmās olimpiskās spēles, kurās piedalījās dalībnieki no tagadējās Latvijas teritorijas. H. Blaus bija pirmais olimpiskais medaḷnieks, daudzu sporta biedrību pārstāvis un sporta darbinieks laikā no 1907. līdz 1938. gadam. Starpkaru gados viṇš bija Latvijas meistars un Latvijas rekordists stenda šaušanā (1926-1938) un aktīvi iesaistījās sporta 
dzīvē: kā daiḷslidotājs pārstāvēja 1. Rīgas Riteņbraucēju biedrību, kurā vadīja arī Tenisa sekciju un piedalījās Sporta komisijā; darbojās Latvijas Pareizu medību un šaušanas biedrībā un Latvijas Medību biedrībā. H. Blaus sporta vēsturē pazīstams arī kā pirmais izcilākais latviešu daiḷslidotājs - Baltijas provinču meistars (1912) un Latvijas meistars (1926, 1928, 1929). Līdzās H. Blaum Āgenskalna Strēlnieku biedrībā sporta gaitas šaušanas sportā sāka arī citi minēto olimpisko spēḷ dalībnieki - RPI studenti - Boriss Pertels (Boris von Pertel; 1888-1955), Pauls Lìts (Paul Lieth; 1883-1950) un Levs Sitins (Lev Sytin; 1891-1973), kā arī Valters Bodnieks (1885-pēc repatr. uz Vāciju) un ĀVSB pārstāvis vieglatlēts, desmitcīnnnieks Alfrēds Alslēbens (Alfred Alsleben; 1891-1930).

Āgenskalna Strēlnieku biedrība par nelielu īres maksu no pilsētas pašvaldības nomāja arī vairākus hektārus lielu zemes gabalu ar kalnainu reljefu Āgenskalna priežu mežā. Pēc Herberta Oskara Alslēbena (Herbert Oscar Alsleben; 1904-1995) atmin̄ām vides plānojumu uzmetuma veidā veica pilsētas arhitekts. Līdzās ierīkotajiem laukumiem šaušanai (arī stenda šaušanai) tika izveidota kamaniṇu trase, slidotava, tenisa laukums, gliemežvāka formā veidota neliela mūzikas estrāde un vairākas saimniecības ēkas [4; 62. lp.]. Vēlākajos gados Strēlnieku biedrība kḷuva par ĀVSB sadarbības partneri.

Vēl pirms Pirmā pasaules kara, 1913. gadā 10. februārī, biedrība atzīmēja 10 gadu darbības svētkus ar vingrošanas demonstrējumiem, svētku mielastu un balli [11].

Biedrības pirmajos 10 gados darbojās Riten,braukšanas, Motoru sporta, Šaušanas sporta un Futbola sekcijas, kā arī tika spēlēts teniss un attīstīts tūrisms. Iecienītajos sporta pasākumos piedalījās arī RPI studenti un absolventi.

Ar Baltijas Olimpiskās komitejas ieteikumu un Krievijas Olimpiskās komitejas akceptu ĀVSB tika uzticēta 2. Krievijas olimpiādes vingroŠanas sacensību organizēšana Rīgā 1914. gada jūlijā. Šì tradīcija turpinājās arī pirmajos divos Latvijas Vispārējos sporta svētkos (1920, 1921) [12].

Pirmā pasaules kara laikā gaišajās ĀVSB nama telpās tika izvietots kara hospitālis. Āgenskalna skaistais mežs kḷuva par krievu armijas militāro mācību zonu: ar izcirstiem kokiem, aizsarggrāvjiem un rokas granātu radītajām bedrēm. Kara izskaṇā biedrības nams bija izpostīts: bez logiem un durvīm, inventārs (vingrošanas rīki) un citas materiālās vērtības izlaupītas, arī 1912. gadā iesvētītais biedrības karogs iznīcināts [4; 57. lp.]. Pirmā pasaules kara gados un tā radīto postījumu dēḷ sporta dzīve Âgenskalnā uz vairākiem gadiem bija pārtraukta. 


\section{Biedrības darbība no 1921. līdz 1939. gadam}

Pēc Pirmā pasaules kara un Latvijas Republikas proklamēšanas vācbaltiešu organizācijas, tostarp sporta biedrības, atjaunoja darbību un attīstīja sporta kultūru jaunajos apstākḷos. 20. gadsimta divdesmitajos gados mainījās Pārdaugavas vācbaltiešu organizāciju sadarbības formas, biedrībām apvienojoties un konsolidējot resursus.

Vācbaltiešu sabiedrība bija nopietnas izvēles priekšā: vai atjaunot Pārdaugavas lielāko sporta biedrību - ĀVSB. Lai gan ar amatnieku pašaizliedzīgu darbu vingrošanas nama lielākā daḷa tika atjaunota jau 1921. gada beigās [4; 58. lp.], biedrība oficiāli darbību atsāka vēlāk nekā citas - ĀVSB Statūti tika pārreǵistrēti tikai 1924. gada 30. janvārī [7; 40. lp.]. 1929. gadā vēlreiz tika pārregistrēti pārveidotie Statūti [7; 45.-48. lp.].

Biedrības dzīvē starpkaru laikā tradicionālajiem sporta veidiem vingrošanai, ritenbraukšanai, futbolam, tenisam, tūrismam, vieglatlētikai, jāšanas un šaušanas sportam un motoru sportam pievienojās bendijs - hokejs ar bumbinu (bandy; 1922), airēšana (1933) [13], sporta spēles - basketbols, volejbols (divdesmito gadu vidū regulāri notika grupu turnīri dāmām, kungiem, meitenēm un zēniem) un handbols. Biedrības paspārnē darbojās 12 dažādu sporta veidu sekcijas: vingrošanas (56 dalībnieki); riteņbraukšanas (70); boulinga (bumbošanas, 17); motoru sporta (22); galda tenisa (40); šaušanas (44); ūdens sporta (41); handbola (rokas balles, 42); tenisa (58); jāšanas sporta (8); vieglatlētikas (15); slēpošanas (41) [14; 2.-3. lp.]. Biedrība veicināja gan ziemas, gan vasaras sporta veidu attīstību, un tiem bija nodrošināta materiālā bāze. Piemēram, bendija komanda trenējās slidotavā netālu no ĀVSB nama.

1923. gada 24. oktobrī tika registrēti ĀVSB partnera - Āgenskalna Strēlnieku biedrības - jaunie Statūti [15], un tā atjaunoja darbību [16; 5. lp.].

1926. gada nogalē Āgenskalna Slidkalna biedrība izsludināja biedrības likvidāciju un pievienojās ĀVSB [17], taču pilnībā likvidācija tika pabeigta tikai 1931. gadā. Kamaninuu trase Āgenskalna priedēs, Švarcmuižas un Kristapa ielas stūrī, ko 1910. gadā pārṇēma un veiksmīgi attīstīja Āgenskalna Strēlnieku biedrība, 20. gadu vidū piedzìvoja panīkumu. Slidkalna biedrībai tomēr neizdevās sakārtot un uzturēt trases. Kamaniṇu sporta cienītāji presē žēlojās, ka Āgenskalns palicis bez ziemas sporta [18]. Apvienošanās ar ĀVSB pavēra iespējas nostabilizēt ziemas sporta veidu - bobsleja, skeletona un kamaninu sporta - attīstību, kas vēl arvien bija vācbaltiešu prioritāte. Tomēr šie sporta veidi dārdzības un tradīciju trūkuma dēḷ latviešu sabiedrībā 
popularitāti neguva. 1927. gada beigās ĀVSB kḷuva par Latvijas Ziemas sporta savienības biedri [19].

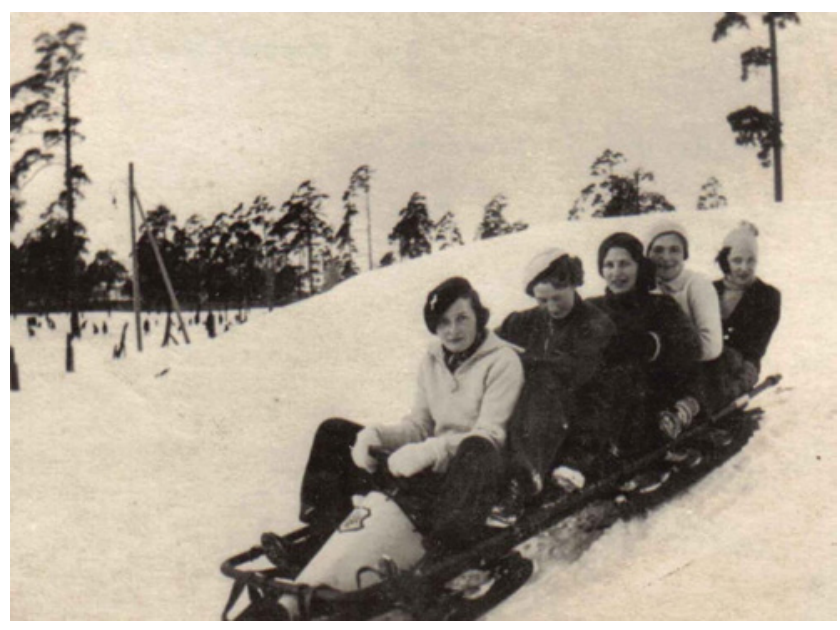

3. attēls. Dāmas Āgenskalna slidkalniṇā (1934).

1928. gada 19.-26. februārī Fiziskas audzināšanas un sporta propagandas nedēḷā vienam no pasākumiem - dažādu kamaniṇu sporta demonstrējumiem - tika izvēlētas Āgenskalna ledus kalna trases [20].

ĀVSB kopā ar Latvijas Motociklistu biedrību, Kurzemes Motociklistu biedrību un Rīgas Motorsporta klubu 1929. gadā dibināja Latvijas Motosporta savienību [21]. ĀVSB Motorporta sekcijā bija registrēti 32 motocikli un septiñi auto [4;60. lp.].

20. gadsimta divdesmito gadu beigās ĀVSB iestājās arī Latvijas Galda tenisa savienībā un 1936. gada novembrī kḷuva par Latvijas Basketbola savienības biedri [22].

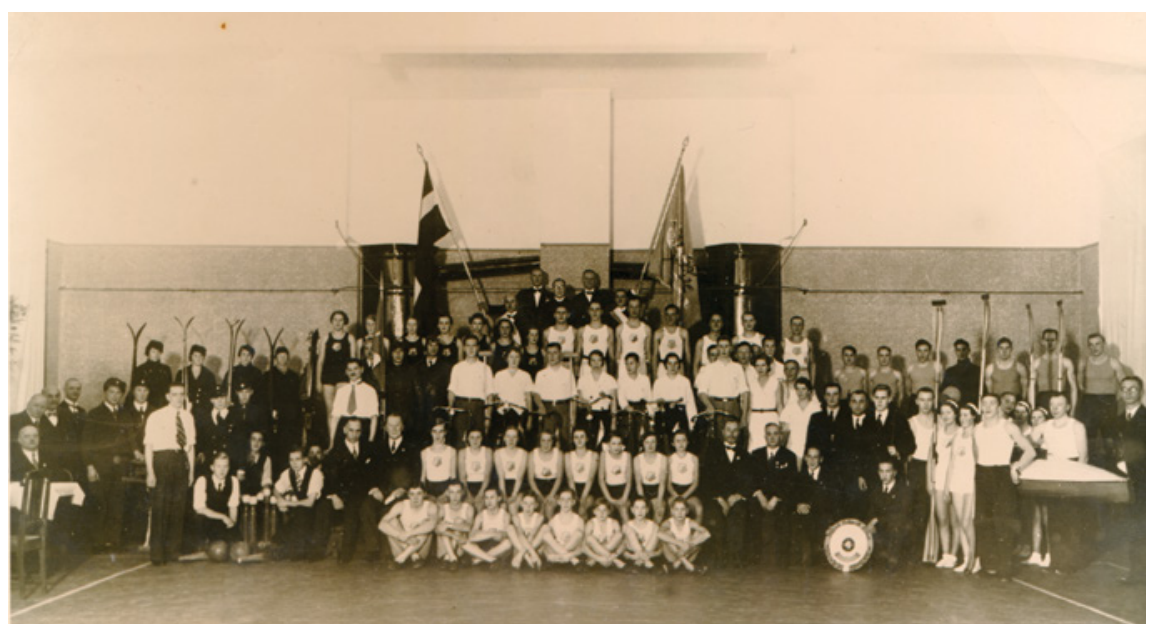

4. attēls. ĀVSB tradicionālais sporta sezonas noslēguma pasākums 1937. gada rudenī. 
ĀVSB starptautiskie kontakti vispirms saistījās ar Vācijas tradicionālajiem vingrošanas un sporta svētkiem, kuros ĀVSB sportisti līdz ar citiem vācbaltiešu vingrotājiem piedalījās svētkos Minhenē (1923), Kelnē (1928), Štutgartē (1933) un Vroclavā (1938). Izcilākos panākumus guva A. Alslēbens, kurš 13. Vācijas vingrošanas svētkos Minhenē un 14. svētkos Kelnē bija godalgoto atlētu vidū vingrošanā un daudzcīnnā.

1934. gadā ĀVSB bija Latvijas Vispārējo tautas sporta svētku dalībniece Rīgā, Rīgas pilsētas stadionā. No 1920. līdz 1939. gadam āgenskalnieši piedalījās Vispārējos Latvijas sporta svētkos (Latvijas olimpiādēs), arī tautas riteṇbraukšanas svētkos - Vienības braucienos (1936-1939).

Pēdējais solis Āgenskalna vācbaltiešu sporta biedrību konsolidācijā bija ĀVSB 1938. gada 30. aprīḷa pilnsapulcē pieñemtais lēmums apvienoties ar Āgenskalna Strēlnieku biedrību, kurai nebija nekustamo īpašumu [23]. 11 šaušanas sporta entuziastu pievienojās citu sporta veidu pulkam ĀVSB paspārnē [15; 12. lp.]. Garais apvienošanās process bija noslēdzies. Biedrības nekustamo īpašumu vērtība bija pieaugusi līdz 220000 latu [24].

1938. gada 5. februārī ĀVSB atzīmēja 35 gadu pastāvēšanas svētkus. Biedrības dzīvi no 1934. līdz 1939. gadam vadīja direktors inženieris Svens Heinrihs Fedors fon Šnakenburgs (Swen Heinrich Fedor von Schnakenburg; 1876-1945).

Biedrībā darbojās 340 personas [14; 2.-3. lp.]. Biedru gada maksa pieaugušajiem bija 8 lati, jauniešiem līdz 18 gadiem - 6 lati [15; 11. lp.].

5. attēls. ĀVSB vieglatlēti (1938). Trešais no kreisās: H. O. Alslēbens.

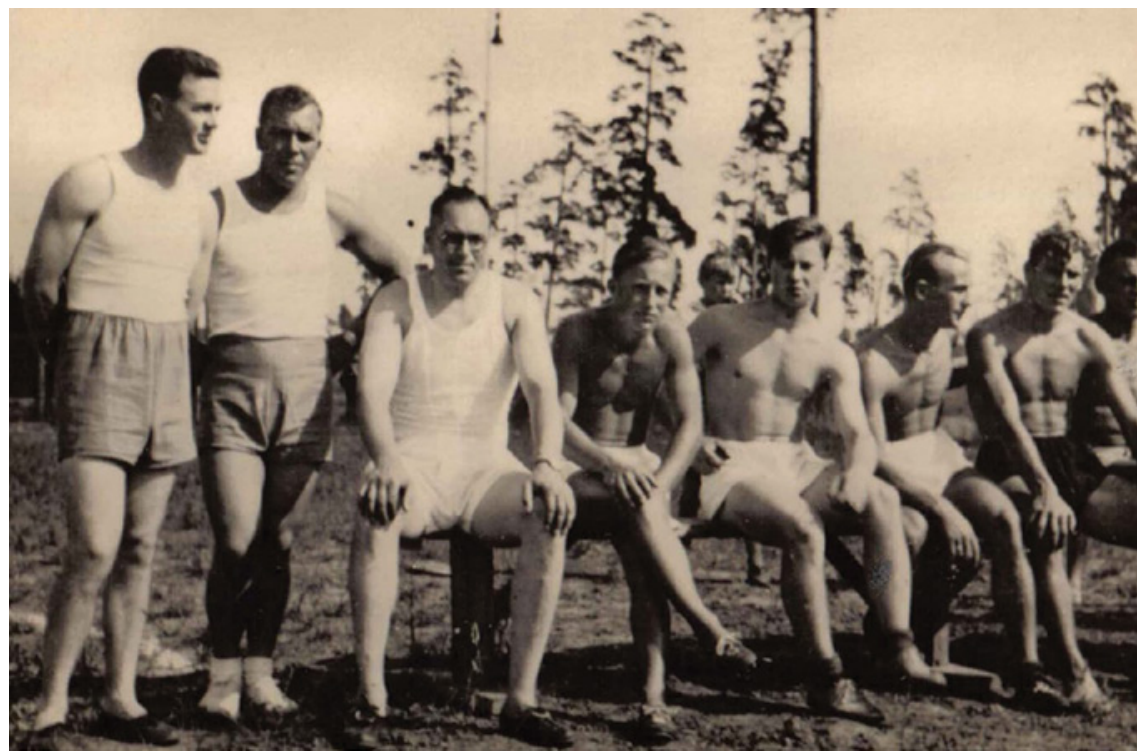


1938. gada reǵistrēto Statūtu 8. punktā tika iekḷauta norma par to, ka biedrībai ir tiesības vadīt vingrošanas un sporta stundas zēniem un meitenēm, kas jaunāki par 16 gadiem un kas nevar oficiāli kḷūt par organizācijas biedriem [15; 27. lp.]. Biedrības biedri sporta stundas vadīja arī agrāk, vēl pirms Pirmā pasaules kara.

Vingrotāju pulku regulāri papildināja skolu audzēkṇi, vingrošanas svētku priekšnesumos iesaistot Rīgas pilsētas 6. un 7. vācu pamatskolas audzēkn,us, kas piedalījās vingrošanas svētku priekšnesumos [8; 32., 33. lp.].

Līdz ar Ūdenssporta sekcijas izveidošanu sāka attīstīties airēšanas sports. Vingrošanas biedrības 24 airu laivas, to skaitā - divas sacīkšu laivas, balti zilā krāsā bija noenkurotas 1. Baltijas Peldēšanas biedrības teritorijā Daugavas kreisajā krastā, kur ĀVSB bija izbūvēta sava slēgtā laivu novietne [4; 65. lp.]. Pēc savstarpējas vienošanās ziemā peldētāji savukārt izmantoja ĀVSB vingrotavu [4; 60. lp.].

Katru gadu notika tā dēvētā Lielā tikšanās (Grosses Treffen) pie ūden,iem, kurā piedalījās visu sporta sekciju biedri. Otrs lielākais ūdens sporta pasākums - ceḷojošā sudraba kausa izcīṇa airēšanā divniekiem meistarbrauciens jeb «Gymkhana» ar ātruma, veiklības un dažādu šḳēršlu pārvarēšanas elementiem.

Vasaras sezonas noslēgumā - oktobrī - biedrības sportisti pulcējās lielajos Rudens svētkos ar priekšnesumiem, godalgu dalīšanu, mūzikas kapelu muzicēšanu, aktieru un burvju mākslinieku uzstāšanos, portretu siluetu un karikatūru zīmētājiem un citām jautrām izdarībām.

1939. gadā saskaṇā ar Likumu par bezpel̦nas biedrībām un to savienībām un Līgumu par vācu tautības Latvijas pilsoṇu pārvietošanu uz Vāciju [25] darbību beidza 19 vācbaltiešu sporta biedrības [26]. 1939. gada 4. novembrī visas vācbaltiešu sporta biedrības, arī ĀVSB [27], tika slēgtas [28].

Sākoties vācbaltiešu sporta biedrību likvidācijas procesam, tika iecelti šo biedrību likvidatori. Par ĀVSB likvidatoriem iecēla Latvijas Fiziskās kultūras un sporta komitejas generālsekretāru Albertu Rumbu (1892-1962) un Aizsargu štāba saimniecības dal̦as priekšnieku Frici Eduardu Upelinci (1894-1950) [14; 7. lp.] - pēc izglītības tautsaimnieku, Latvijas Universitātes absolventu (1930), kurš RPI savulaik studējis k,īmiju. Vēlāk gan A. Rumba no šì pienākuma atteicās, un viṇa vietā tika iecelts Aleksandrs Ūdris (1902-1978). No biedrības valdes atbildību par nekustamā un kustamo mantu uzṇēmās prezidents inženieris S. H. F. fon Šnakenburgs, priekšsēdētāja biedrs, nama pārvaldītājs jeb mājzinis H. 0. Alslēbens un biedrības tenisa nozares vadītājs Fridrihs Kreicers (Fridrich Kreizer; 1889-?) [8; 54. lp]. Uz vinu pleciem gūlās atbildība par 36 gados radītajām vērtībām. 
Biedrības likvidācijas process sākās 1939. gada 3. septembrī un ilga vairākus gadus, noslēdzoties 1941. gada 28. februārī ar likvidatoru pēdējo ziṇojumu par procesa izbeigšanu [29; 34. lp.].

Nams un biedrības teritorija tika izmantotas kā vācu tautības bijušo Latvijas pilson,u repatriācijas mantu iesain,ošanas punkts pirms Latvijas atstāšanas [30].

1939. gada 16. novembrī Baldones ielā 7 ieradās sabiedrisko lietu ministra ieceltie biedrības likvidatori F. E. Upelincis un A. Ūdris, lai pārṇemtu divus nekustamos īpašumus, kas 1938. gada bilancē novērtēti par 71 740,84 latiem [27; 11. lp.]. Latvijas Hipotēkas bankas kasators būvinženieris Teodors Rušiňš (1899-1967), LU absolvents (1928), kurš studijas iesāka RPI, 1940. gadā veica likvidējamās biedrības nekustāmā īpašuma novērtējumu - 161127 latu apmērā [29; 22. lp.].

20. novembrī ĀVSB valde iesniedza biedrības likvidatoriem lūgumu par atḷauju pēc aktos iekḷautajiem mantu sarakstiem ar turpat 900 lietām par kustamās mantas izvešanu uz Vāciju. Saraksti vēlāk tika papildināti ar ierakstiem: «nolietots», «nedarbojas», «saplēsts», «salauzts» utt. Starp mēbelēm - galdiem, krēsliem, dīvāniem, skapjiem, lampām, spoguḷiem - un citām uzskaitītām mantām, kas visas atzīmētas kā nolietotas, tātad - nevērtīgas, bija arī sporta lietas volejbolam, šaušanai, vieglatlētikai, smagatlētikai, tenisam, tiesnešu aprīkojumi un arī četras bobsleja kamanas. Sabiedrisko lietu ministrijai par to, ka mantas izved uz ārzemēm, iebildumu nebija. Biedrības pārstāvjiem laika bija atlicis pavisam maz, starptautiskā situācija mainījās no dienas dienā, saspīlētība un kara tuvums ierēdniecību bija padarījusi nervozāku, bet ĀVSB īpašums neglābjami tika izlaupīts un demolēts.

Uz vingrošanas zāli pretendēja Latvijas Republikas Sabiedrisko lietu ministrija un Izglītības ministrija, savukārt uz manēžu un zirgu stallıiem - Kara ministrija, lai to nodotu 5. Rīgas Aizsargu pulka Sporta klubam [31; 21. lp.]. Vēlāk arī vingrotavu ieguva minētais aizsargu klubs, un to sāka dēvēt par Aizsargu vingrotavu [32]. 1940. gada aprīlī tajā notika aizsargu basketbola meistarsacīkstes [33].

1940. gada 3. augustā oficiāli ar Kara ministrijas Apgādes pārvaldes Būvniecības daḷas pārstāvju starpniecību ĀVSB visa manta tika nodota Latvijas armijas rīcībā [29; 24. lp.]. Biedrībai par mantas lietošanu nekāda atlīdzība (samaksa) nebija paredzēta.

Vācijas valdības pilnvarotais biedrību lietās Latvijā G. Bērents (G. Baerent; ?-?) saskaṇā ar repatriācijas līgumu biedrības kustamo mantu bija tiesīgs pārdot Sarkanai Armijai, kas piekrita mantas atpirkt [29; 33. lp.]. Sarakste par to pirkšanu vai izvešanu uz Vāciju nedeva rezultātus, un mantu skaits krietni saruka, jo tās acīmredzot tika izsaimniekotas. 
Latvijas Padomju Sociālistiskās Republikas Iekšlietu tautas komisariāta Biedrību nodaḷa neiebilda, ka biedrības kustamais un nekustamais īpašums nonāk Sarkanās Armijas dal̦u rīcībā. Sarkanā Armija lūdza atl̦auju Biedrību nodaḷai ĀVSB kustamo īpašumu atpirkt.

Likvidācija bija ievilkusies vairāku mēnešu garumā. 1940. gada 9. septembrī tika rakstīts Ziṇojums ar lūgumu rīkoties, jo «1) likvidācija jau velkas vairākus mēnešus, 2) likvidējamā manta vairākkārtīgi bijusi jānodod un jāpārṇem dažādiem lietotājiem, kas sarežǵī likvidācijas darbu un pavairo izdevumus, 3) likvidējamai biedrībai piederošā nekustamā un kustāmā manta ir speciāli būvēta, iegādāta un piemērota dažādu sporta veidu piekopšanai, un mantas kopvērtība ir apmēram 16500 latu. Likvidatori lūdz iekšlietu komisariātu steidzoši izlemt jautājumu par Āgenskalna vingrošanas un sporta biedrībai piederošās nekustamās un kustamās mantas galīgu piešḳiršanu kādai organizācijai fiziskās kultūras veicināšanai» (autores piezīme, origínālā pasvītrots ar sarkanu zīmuli) [27; 44.lp.].

1940. gada 9. septembrī Latvijas armijas karaspēka daḷas atstāja Baldones ielas 7 nama telpas un teritoriju. Bija pienemts mantu apsargs Jānis Tropiṇš (?-?), kurš strādāja par pieciem latiem dienā. 21. septembrī biedrības īpašumus pārṇēma Sarkanā Armija, kas tos neatpirka.

Vingrotavas namā telpas bija ar izdauzītiem logiem, bojātām centrālapkures ierīcēm, dal̦a žoga gar Baldones ielu bija noplēsta.

Latvijas Hipotēku bankā biedrībai palika parāds aizdevumu veidā 7461,88 lati [29; 27. lp.]. 1940. gada oktobrī Latvijas Hipotēkas banku pārveidoja par Komunālo banku, un ĀSVB vecās bankas parāds jeb jaunais «apvienotais - pārkārtotais aizdevums» 3300 latu apmērā bija atmaksājams ar 5,5 \% un dzēšams 28 gadu laikā, sākot no 1940. gada 1. novembra [29; 31. lp.].

1940. gada izskaṇā Latvijas meistarsacīkstēs vingrošanā nepiedalījās neviena vācbaltiešu vingrotāju biedrība [34], arī ĀVSB vingrošanas sekcijas 56 dalībnieki. 1941. gada 28. februārī likvidatori iesniedza ziṇojumu Komunālās saimniecības komisariāta Galvenai dzīvokḷu pārvaldei par to, «ka Āgenskalna vingrošanas un sporta biedrības likvidācija tiek izbeigta» [29; 34. lp.].

\section{Āgenskalna dzeltenais nams un ĀSVB}

19. gadsimta otrajā pusē vācbaltiešu un latviešu arhitekti Kurzemes un Vidzemes guberñās piedalījās gan sporta namu projektēšanā un celšanā, gan iesaistījās sporta biedrību dzīvē, piedalījās sporta sacensībās. 
Par jūgendstilā būvēto ĀVSB namu un biedrības darbību galvenokārt liecina apraksti vācu un latviešu presē un LVA LVVA materiāli, kā arī vācbaltiešu atmiṇu publicējumi dažādu formu izdevumos. Īpaši atzīmējama Alslēbenu dzimtas hronika [4], kuras autors ir ĀVSB biedrs un viens no vadītājiem H. O. Alslēbens. Hronika sniedz ieskatu ne tikai sabiedriski politiskajos notikumos un saimnieciskās dzīves pārvērtībās, bet arī par to ietekmi uz kultūras un sporta procesiem vairāku gadsimtu garumā.

No 1903. līdz 1910. gadam ĀVSB nebija pastāvīgas mājvietas vai sava īpašuma. Biedrības darbības pirmajos gados pagaidu mītne atradās Āgenskalna parkā, jau minētajā G. J. Eberta namā. Pasākumi ar publiskiem vingrošanas demonstrējumiem notika parkā, arī uz Vasaras teātra skatuves vai Āgenskalna Saviesīgās biedrības nama telpās, Baložu ielā 15, izmantota tika arī pagaidu vingrotava Slokas ielā 17 [35]. Pēc Baložu ielas 15 sporta zāles pārbūves un Āgenskalna Strēlnieku biedrības nodibināšanas 1907. gadā šĩ nama telpas nomāja šaušanas sporta entuziasti.

6. attēls. ĀVSB iegūtā zemesgabala Baldones ielā 7 situācijas plāns (1910).

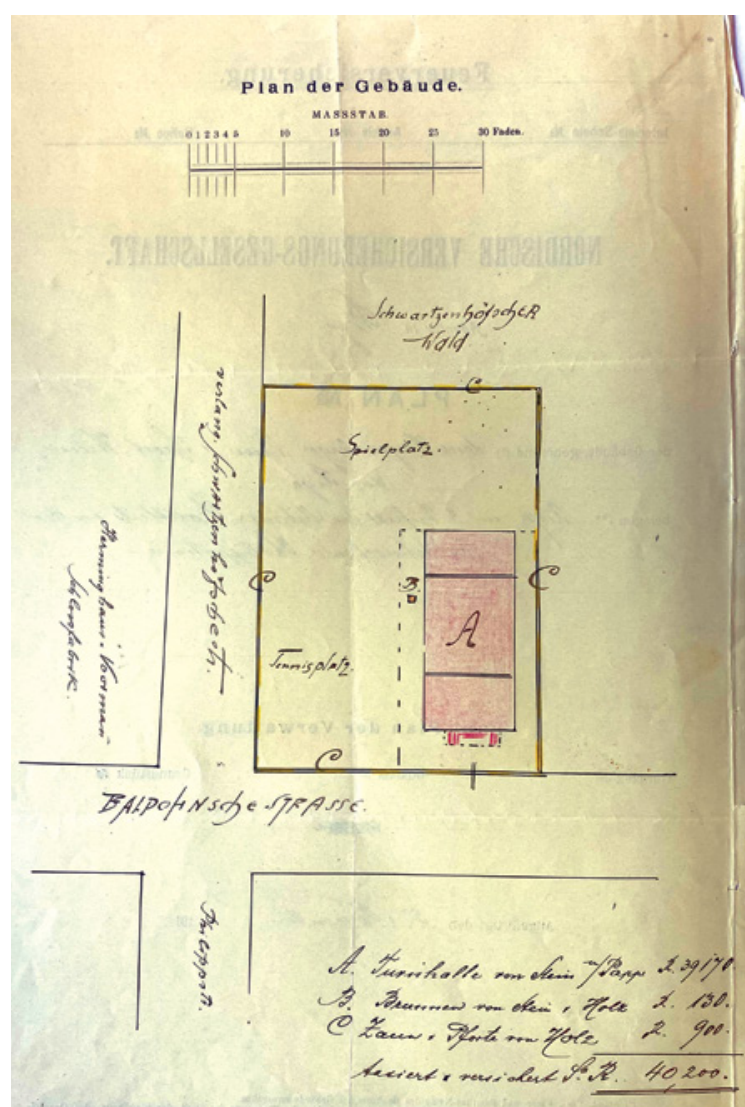

Āgenskalna

Vingrošanas un sporta biedrības darbība un nams Baldones ielā 7 
Par ēkas arhitektūru un celtniecības gaitu liecina arhitektu, RPI Arhitektūras nodal̦as absolventu Leopolda Rīmera (Leopold Riemer; 1880-1923?) un H. Blaua, kā arī Latvijas Universitātes Arhitektūras fakultātes absolventa Alfrēda Laukirbes (1901-1993) izstrādātās skices un plāni. Foto materiāls par būves ārskatiem un telpu iekšskatiem, kas varētu sniegt pārliecinošu priekšstatu par namu un tās pārbūvi no 1910. līdz 1940. gadam, ir niecīgs. Lìdz šim saglabājušās tikai nedaudzas fotogrāfijas, kas ievietotas Sabiedrisko lietu ministrijas Preses un biedrību departamenta materiālos, t. i., ĀVSB likvidācijas dokumentos [36; 1. lp.], kā arī minētajā Alslēbenu dzimtas hronikā.

20. gadsimta sākumā G. J. Eberta nams daudziem vingrot gribētājiem kḷuva par šauru un mazu [4; 56. lp.], un biedrības Celtniecības komisija sāka risināt jautājumu par sava nama celtniecību. Komisijas vadītājs bija inženieris Raimunds Kovarčiks (Raimund Kowarzyk; 1882-pēc 1957, Vācijā), kurš augstskolas diplomu bija ieguvis Minhenē, Vācijā. Šo amatu viṇam 1909. gada 24. janvāra ĀVSB kopsapulcē uzticēja biedrības pirmais prezidents 0 . Zuks. Komisijas mērkis - risināt jautājumu par nama celtniecību. Sākotnēji tika noskatīti zemes gabali Daugavgrīvas un Āgenskalna ielā, taču šìm vietām trūka tālākas perspektīvas sporta attīstībai [24].

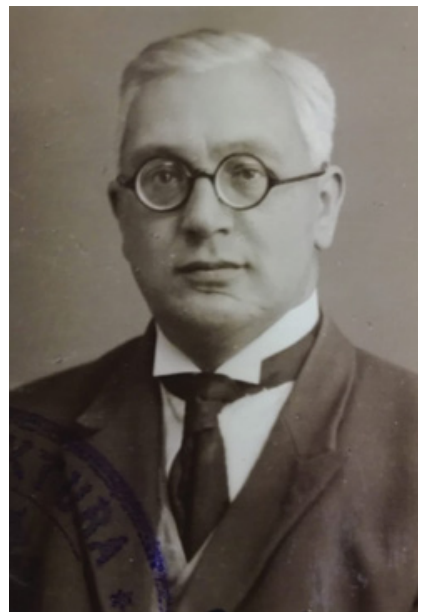

7. attēls. ĀVSB priekšsēdētājs (1909-1926) inženieris R. Kovarčiks (ap 1930).

1910. gada 13. februārī Āgenskalna parka nama zālē notika biedrības kopsapulce, kurā pienēma Celtniecības komisijas ziṇojumu ar priekšlikumu pirkt zemes gabalu Baldones un Švarcmuižas ielas stūrī, kas atradās Rīgas pilsētas 2. Jelgavas priekšpilsētas daḷā. 253 kvadrātasis jeb 1155 kvadrātmetru lielais zemes gabals tika iegādāts par 1211 cara rubl̦iem. İpašumu novērtēja par 2800 cara rubḷiem. Biedrība divu gadu laikā apṇēmās uzcelt namu ar vingrotavu. 
Inženieri Emīls Bartels (Emil Barthels; ?-?) un R. Kovarčiks saṇēma pilnvarojumu slēgt pirkuma līgumu ar Rīgas tirgotāju un arī maizniekmeistaru Oto Grīnbergu (1870-pēc izcel̦ošanas uz Vāciju 1939) [7; 11. lp.]. O. Grīnbergs bija vēlākā ĀVSB nekustāmā īpašuma apakšīpašnieks, savukārt virsīpašnieks - Švarcmuižas īpašnieks Johans Kristofs Švarcs (Johann Cristoph Schwartz; 1846-1915), profesors, jurists, Rīgas domnieks, Bāriṇtiesas prezidents, kas tajā laikā dzīvoja Vācijā, Hallē pie Zāles (Halle an der Saale). Viṇa interešu pārstāvis tiesiski mantiskajos darījumos bija RVB prezidents, ĀVSB Goda biedrs advokāts Konrads Bornhaupts (Conrad Bornhaupt; 1841-1914) [7; 13. lp.].

Švarcmuižas īpašnieks pārdeva minēto zemesgabalu ar noteikumiem: 1) gadu uz priekšu samaksāt ikgadējo zemes nodokli 20 rubḷus; 2) neierīkot viesnīcas vai tirgošanās vietas un nenodarboties ar dzērienu tirdzniecību; 3) nedalīt īpašumu bez tiešā zemes īpašnieka piekrišanas. Pirkšanas-pārdošanas līgums tika noslēgts 1910. gada 13. aprīlī [7; 11. lp.]. 1910. gada 19. aprīlī svinīgi tika ielikts jaunā biedrības nama pamatakmens [37].

Divstāvu jūgendstila nama skiču un plānojuma autors bija Rīgas arhitekts, RPI Arhitektūras nodal̦as absolvents (1906) L. Rīmers. Viṇš bija strādājis par zīmēšanas skolotāju Kuldīgas ǵimnāzijā (1906-1907) un bijis šìs pilsētas arhitekts (1907-1908), vēlāk - par matemātikas skolotāju Tomskas komercskolā Krievijā (1908-1909), no 1909. gada bija Rīgas pilsētas arhitekts [38].

Tā laika arhitektūras un arī modes iezīme - jūgendstils, kas veidojās 19. gadsimta beigās un pastāvēja līdz Pirmajam pasaules karam, ietekmēja arī, piemēram, sporta sacensību programmu grafisko rotājumu un burtu izvēli ar jaunā stila iezīmēm.
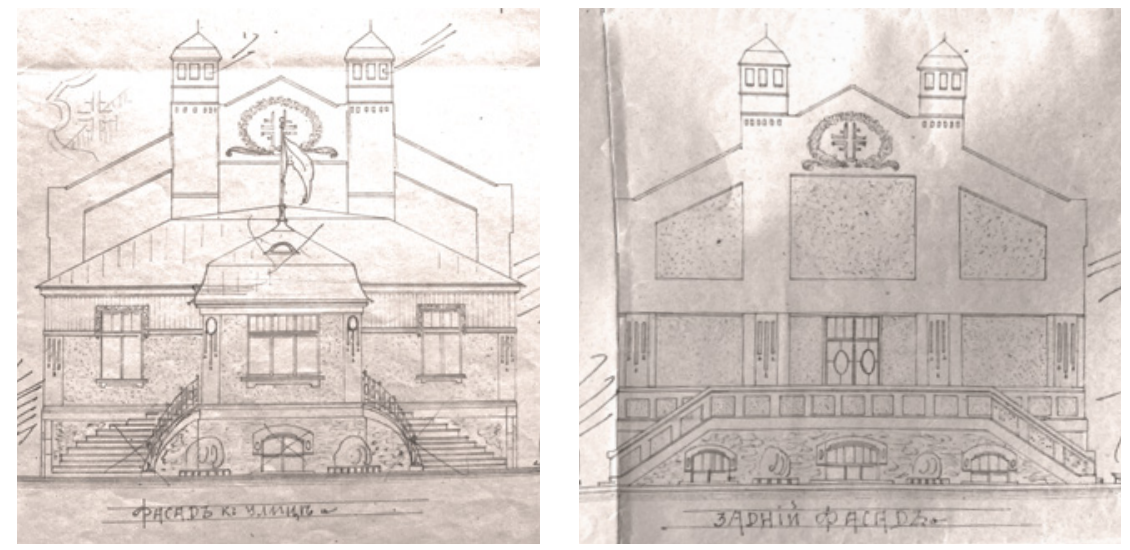

8. attēls. Arhitekta L. Rīmera ĀVSB nama fasādes skice ar galveno ieeju no Baldones ielas un gala fasādes skice - Āgenskalna ielas pusē (1910). 


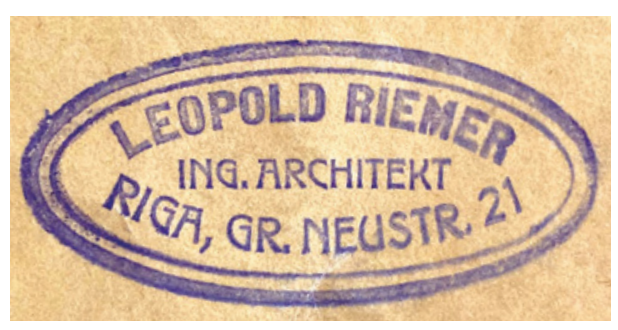

9. attēls. L. Rīmera zīmogs zem 1910. gadā izstrādātā ĀVSB nama projekta.

Vidzemes guberņas pārvaldes Būvuzraudzības komisija apstiprināja L. Rīmera projektu 1910. gada 12. jūnijā [39]. Pēc arhitekta projekta skicēm nama galu fasādes zelmeni bija iecerēts rotāt ar reljefā veidotu cilni - ĀVSB gerboni - četru «F» burtu stilizētu savijumu, kam apkārt ir vainags. Vēlāk arhitekta A. Laukirbes 1935. gada nama pārbūves skicēs biedrības gerbonis saglabāts un jau ietverts vapenī [39]. Ģerbonis rotāja ēku līdz pat biedrības likvidācijai 1940. gadā. Par logo to izmantoja arī biedrības oficiālo dokumentu veidlapās.

Īpašums Baldones ielā 11 (tagad - 7) stiepās līdz Švarcmuižas mežam, un viena no tā malām robežojās ar tagadējo Vīlipa ielu. Galvenā fasāde ar ieeju bija no Baldones ielas. Sākotnēji īpašumā bija sporta laukums, tenisa laukums un nams ar vingrotavu [40; 3. lp.].

No galvenās ieejas Baldones ielā kāpnes puslokā no labās un kreisās puses veda uz pirmā stāva vestibilu. Pirmajā stāvā bija garderobe, vingrošanas zāle, telpa vingrošanas rīkiem, kas bija pārveidojama un izmantojama arī kā skatuve, pārǵērbšanās telpa, biedrības valdes sēžu un sabiedrisko norišu zāle, tualete. No vingrotavas bija izeja uz terasi, kas pavēra skatu uz sporta laukumu un Švarcmuižas mežu. Pagrabstāvā atradās bumbotava jeb boulinga zāle, biljarda zāle, ēdamzāle, virtuve un noliktavas [39; 56. lp.].

1910. gada 14. novembrī notika ĀVSB nama iesvētīšana un oficiāla darbības atklāšana. Tajā piedalījās 260 viesu no dažādām sabiedriskām organizācijām un vācu sporta biedrībām [41]. Rīga ieguva otru lielāko vingrotavu aiz RVB zāles. Otrās Rīgas Apdrošināšanas biedrības Taksācijas komisija namu novērtēja par 30700 cara rubliem, zemes vērtību - par 1535 rubliem [40; 9. lp.].

Iespaidīgā jūgendstila akmens celtne, kas atradās netālu no vecās Zasumuižas, mežu ieskauta, pacēlās pāri visai apkārtnei, un āgenskalnieši to dēvējuši par lielo dzelteno māju (Gelbe Buda). Tā bijusi iespaidīgākā sabiedriskā celtne Āgenskalnā, kas kalpoja ne tikai sportam, bet arī saviesīgiem pasākumiem dažāda vecuma iedzīvotājiem: te notika religisko svētku un Valpurğu nakts atzīmēšana, ǵimeñu vakari, bērnu svētki, pavasara un rudens svētki, simfoniskās mūzikas koncerti, izglītojoši pasākumi, karnevāli un masku balles. 


\section{Biedrības nama Baldones ielā modernizācija un tālākais liktenis}

Pirmā pasaules kara radītie postījumi, kam sekoja Latvijas brīvības cīnas par neatkarību, uz daudziem gadiem apturēja Āgenskalna un tās apkaimes kultūras un sporta dzīves dabisko attīstību. Tomēr ĀVSB vēlējās paplašināt darbību, kā arī modernizēt savu namu Baldones ielā. 1927. gada 12. aprīlī Centrālā zemes ierīcības komiteja piešķīra ĀVSB īpašumā zemi [42]. Zemes gabala palielināšana turpinājās arī 1929. gadā. Lēmumi radīja labvēlīgus apstākḷus biedrības infrastruktūras attīstībai. Tādējādi mērḳi - paplašināt darbību sporta un kultūras jomā - varēja realizēties.

1927. gada 22. septembrī Rīgas Būvvaldes komisijas sēdē tika apstiprināts arhitekta H. Blaua izstrādātais ĀVSB nama Baldones ielā 11 jumta stāva izbūves projekts. Pārbūves nolūks bija izbūvēt dzivokḷus biedrības nama pārzinim un ekonomam [4; 56. lp.]. 17. novembrī darbi tika pabeigti un piennemti [39; 11.lp.]. Jau 1928. gada 12. februārī namā plaši atzīmēja biedrības 25 gadu pastāvēšanas svētkus ar jauna karoga iesvētīšanu [12].

10. attēls. Arhitekta H. Blaua izstrādātais nama Baldones ielā 11 jumta stāva izbūves projekts (1927).

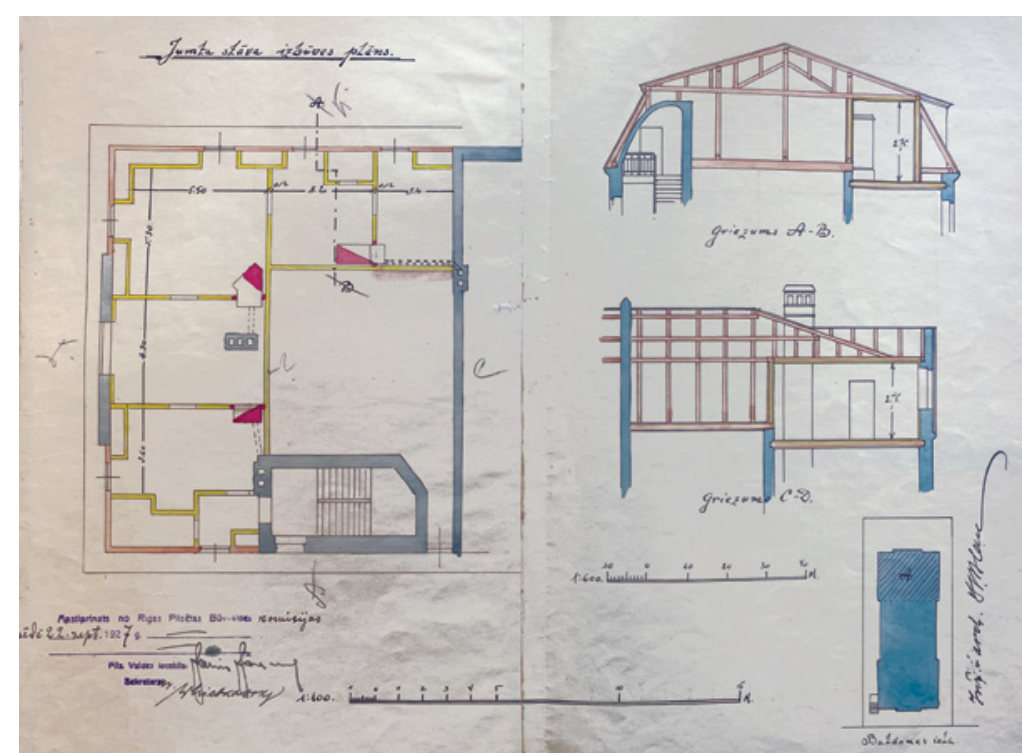

darbība un nozīme apkaimes sporta un sabiedriskajā dzīvē 20. gadsimta trīsdesmitajos gados strauji
auga. Attīstībai bija nepieciešama modernāka, laikam atbilstošāka sabiedriskajā dzīvē 20. gadsimta trīsdesmitajos gados strauji
auga. Attīstībai bija nepieciešama modernāka, laikam atbilstošāka infrastruktūra.

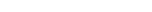


Trīsdesmito gadu vidū biedrība ieguva finansiālu un saimniecisku stabilitāti: tika dzēsts hipotekārais kredīts 25000 cara rubḷu apmērā (1930) [7; 30. lp.], paplašināts nekustamais īpašums, apvienojot divus gruntsgabalus Nr. 156 un Nr. 157, to platība pieauga līdz 3315 kvadrātmetriem (1934) [7; 57. lp.]. 1934. gada 4. jūnijā uz izpirkuma līguma pamata īpašuma tiesības tika nostiprinātas ĀVSB. Pirkuma cena 4010 latu [36; 3. lp.]. 1936. gada 24. oktobrī tika apstiprināts pirkuma līgums jaunam zemes gabalam Āgenskalna ielā 23, kas piekḷāvās esošajam biedrības zemes gabalam. Jaunais zemes gabals tika iegādāts par 22 086,08 latiem. Jaunajā īpašumā izbūvēja koka manēžu un zirgu stallıus. Tas deva iespēju daudzpusīgāk attīstīt biedrības sporta dzīvi, piemēram, attīstīt jāšanas sportu [36; 5. lp.].

ĀVSB kḷūstot turīgākai, varēja domāt par nama labiekārtošanu, tajā skaitā - vingrotavas paplašināšanu un šautuves ierīkošanu. 1930. gadā tika saṇemta aț̣auja par šautuves izbūvi ēkas velvētajā pagraba stāvā, ko izmantoja tikai šaušanai ar mazkalibra ieročiem [39; 13. lp.].

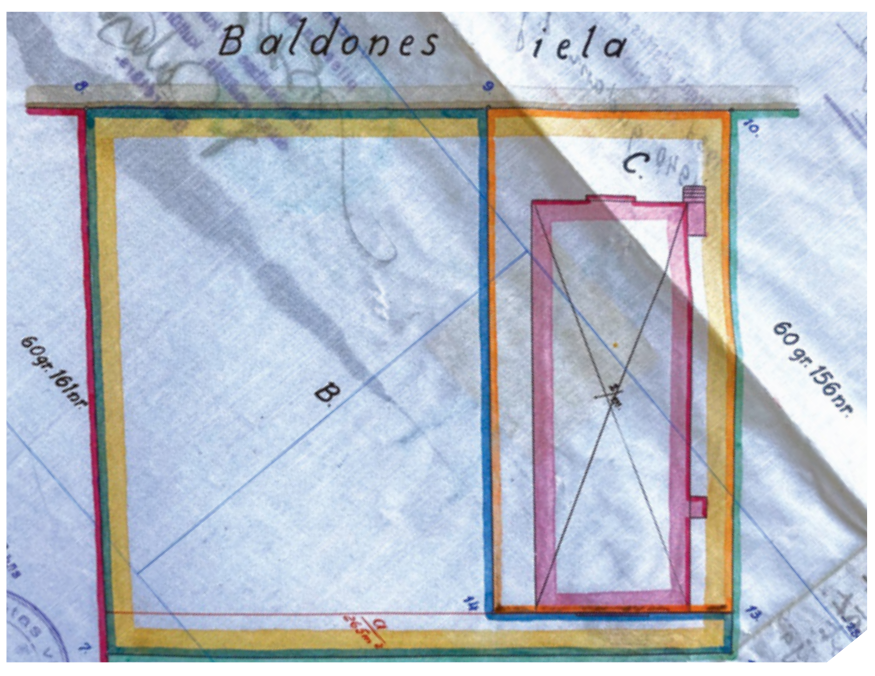

11. attēls. ĀVSB īpašuma situācijas plāns (1934).

1935. gada 7. novembrī tika apstiprināts arhitekta A. Laukirbes projekts ēkas otrā stāva pārbūvei Baldones ielā 7 [39; 17. lp.]. Pēc pārbūves mainījās telpu funkcijas, èka ieguva vaḷēju terasi uz pagalma pusi, trīs vingrotāju gèrrbtuves, biedrības valdes telpu un 257 kvadrātmetrus lielu vingrotavu. Pagrabstāvā bija mazā zāle, bufetes telpa, virtuve, saimniecības palīgtelpas un bumbotava [39; 30. lp.]. 


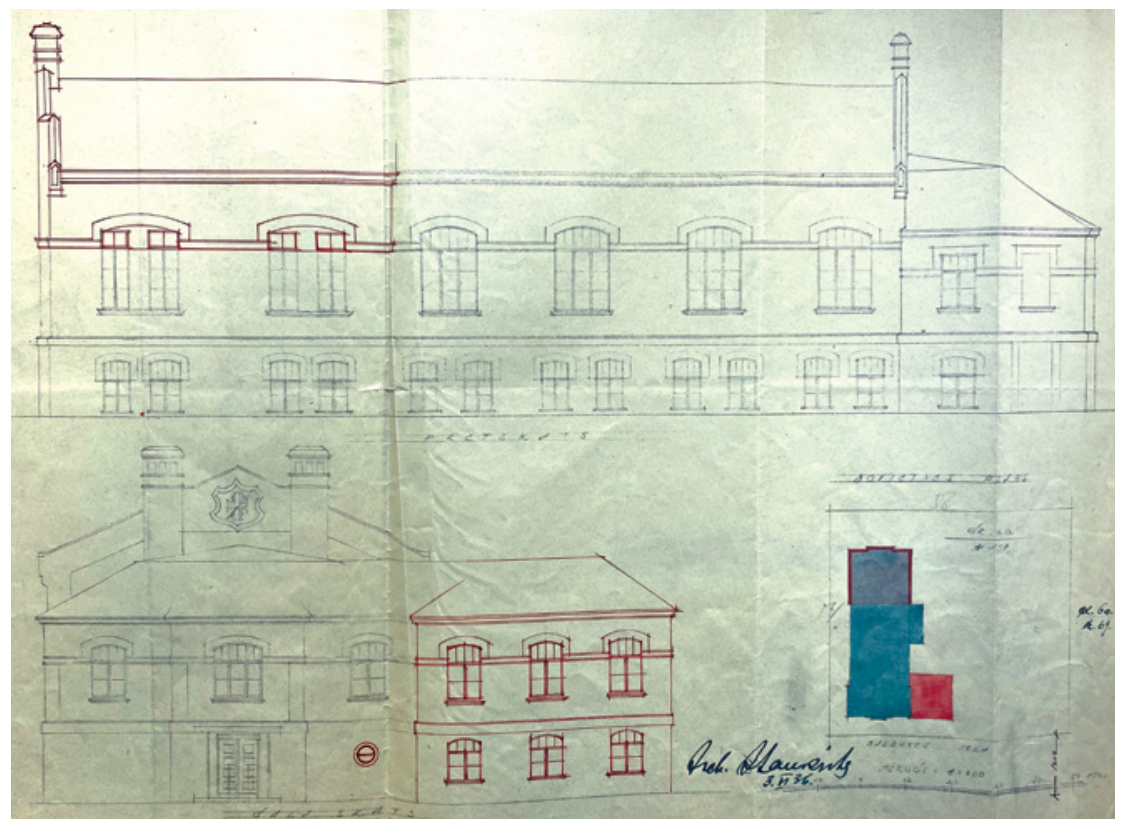

12. attēls. Arhitekta A. Laukirbes ĀVSB nama otrā stāva pārbūves būvprojekts (1935).

1935. gadā ēkai tika uzlikts jauns zviedru cinkotā skārda jumts. Darbi turpinājās arī 1936. gadā, veicot nama otrā stāva pārbūvi un divstāvu nama piebūvi. A. Laukirbes projekts tika apstiprināts 9. jūlijā [39; 28. lp.].

13. attēls. Arhitekta A. Laukirbes ĀVSB nama vingrošanas zāles otrā stāva pārbūves un ēkas piebūves plāns (1936).

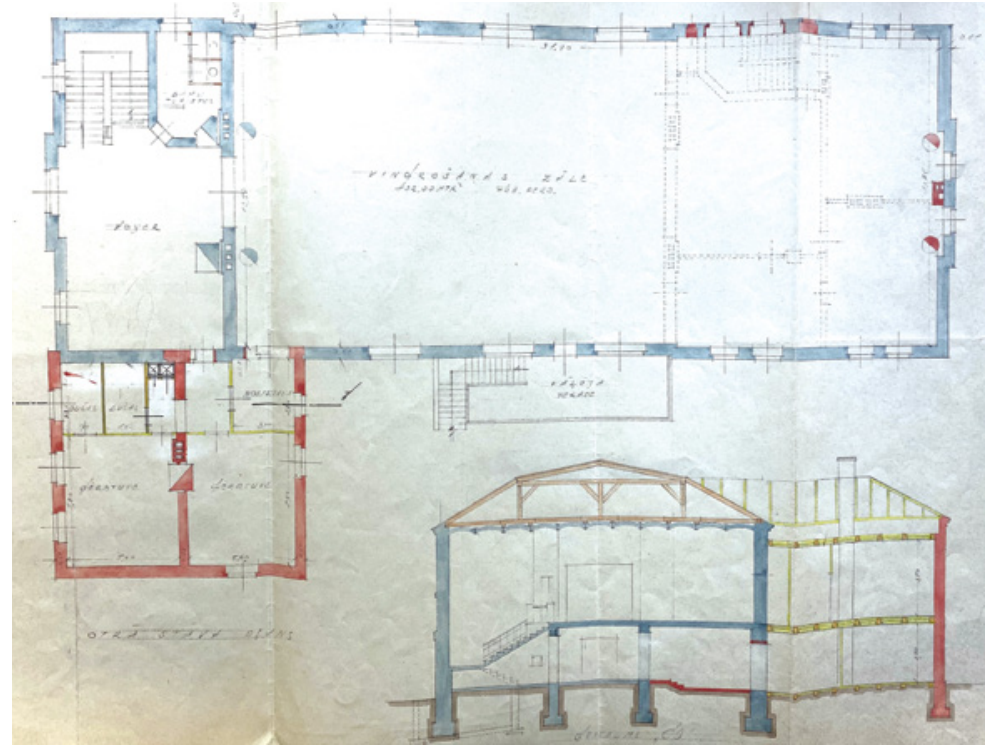


Piebūves pirmajā stāvā bija iecerētas divas dušas telpas, divas gērbtuves un noliktava. Taču lielākais ieguvums bija pārbūvētā 432 kvadrātmetrus lielā vingrošanas zāle. Tās pārbūve tika veikta ar akciju sabiedrības «C. CH. Schmidt Rīgas cementa fabrika» vadības gādību. Tajā pašā gadā ēkā ievilka centrālapkuri un gāzi, kā arī tika mainīta ēkas galvenā fasāde. Būvprojektu kanalizācijai un notekūdeñiem apstiprināja 1937. gada 19. maijā [39; 34. lp.].
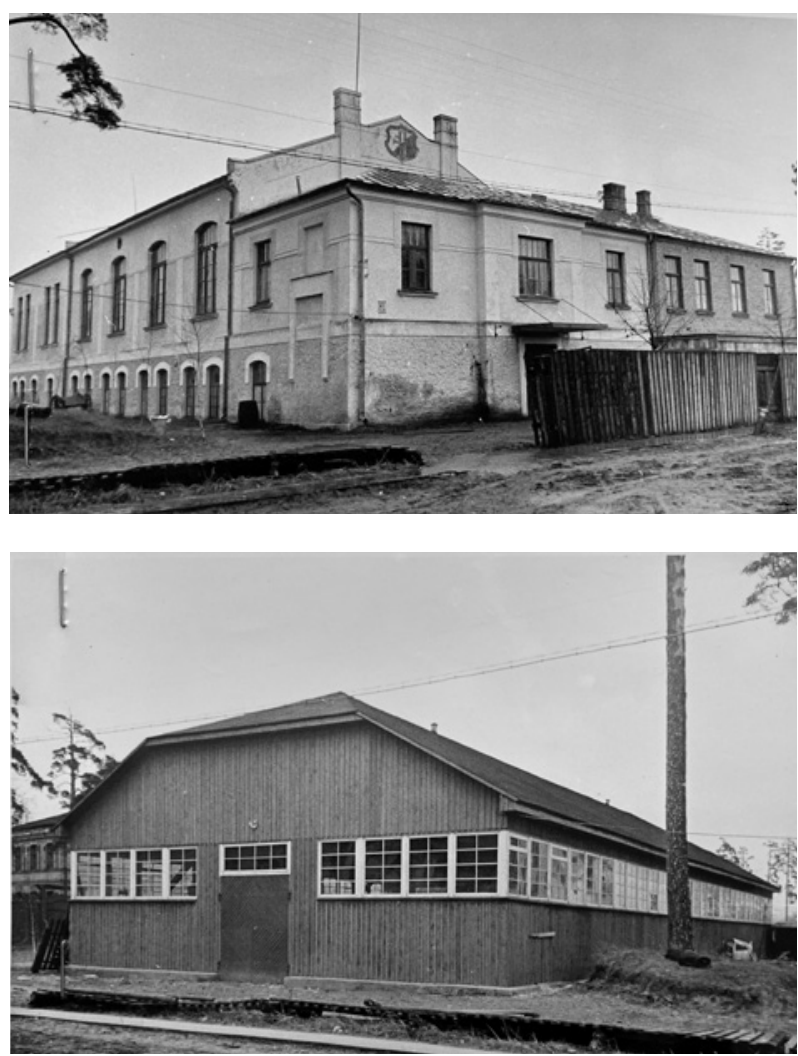

14. attēls. ĀVSB nams ar jaunuzcelto piebūvi (1939).

15. attēls. ĀVSB manēža jāšanas sportam (1939).

Lielākie ieguvēji pēc nama pārbūvēm bija Rīgas tenisisti. Līdz šim viṇiem vienīgā iespēja ziemas sezonā vingrināties spēlē bija Bergmaṇa tenisa zālē Ganību dambī 1 [43]. Pēc pārbūves darbiem ēkā Baldones ielā, vingrošanas zāle tika palielināta, atsakoties no skatuves un dažām palīgtelpām $[4 ; 60$. lp.]. Jaunā zāle pilnībā atbilda tenisa spēles prasībām - ar plašiem laukumiem aiz sānu un gala līnijām. Zāle bija aprīkota tā, lai būtu iespējams spēlēt basketbolu, volejbolu un handbolu. 1936. gada 18. oktobrī ar tenisa paraugdemonstrējumiem atklāja lielāko tenisa zāli Rīgā. 
1937. gadā no 31. janvāra līdz 7. februārim notika pirmais oficiālais tenisa turnīrs slēgtās telpās, kurā piedalījās 13 tenisisti vienspēlēs un astoṇi pāri dubultspēlēs [44]. Jauno slēgto telpu priekšrocības nodrošināja arī ciešāku sadarbību ar 1. Rīgas Riten,braucēju biedrību, kas starpkaru laikā pievērsās arī tenisa spēlei un izmantoja ĀVSB telpas.

Gadu gaitā nama pārbūves bija mainījušas arī telpu izkārtojumu un funkcijas - pirmajā stāvā atradās bumbotava, mazā zāle, bibliotēka, valdes sēžu istaba, šautuve un divi dzīvokḷi - vienistabas un trīsistabu, centrālapkures un trepju telpas, otrajā stāvā - lielā sporta zāle ar palīgtelpām (dušas, sporta rīku un gēerbtuves telpa).

20. gadsimta trīsdesmitajos gados ĀSVB bija izaugusi, paplašinājusies, kḷuvusi par vienu no bagātākajām un ietekmīgākajām vācbaltiešu sporta biedrībām ne tikai Rīgā, bet arī visā Baltijā. Biedrībai rīcībā bija divi nekustamie īpašumi: 3315 kvadrātmetru liels zemes gabals ar namu (41 metru garu, 15 metru platu) Baldones ielā 7; 6062 kvadrātmetru liels zemes gabals ar koka būvi (manēža jāšanas sportam - 40 metru gara, 14 metru plata) Āgenskalna ielā 23 [36; 2. lp.]. Šo īpašumu kopējā vērtība bija 71740 latu [29; 1. lp.]. Sporta un vingrošanas rīki tika iegādāti 14500 latu vērtībā [14; 2. lp.]. Trīs atklātie tenisa laukumi nodrošināja spēles attīstību vasaras mēnešos.

Pēc Otra pasaules kara namu Baldones ielā 7 nodeva sporta biedrībai «Daugava». Ėka piedzīvoja vairākas pārbūves un labiekārtošanas darbus. 1949. gadā ēkai tika piebūvēta jauna katlu telpa un pārbūvētas centrālās apkures, kā arī ventilācijas un kanalizācijas sistēmas, pie pamatiem tika nostiprinātas ēkas nesošās sienas [45]. Tika izbūvēti āra treniṇu laukumi volejbolam, basketbolam, iekštelpās - smagatlētikas zāle un šautuve, bija paredzēts iegādāties modernu sporta aprīkojumu. Plāns iekārtot arī slēpju bāzi un slidotavu netika īstenots, jo augsto gruntsūdeṇu dēḷ, ledum kūstot, ūdens sūcās pagrabstāvā $[46,47]$.
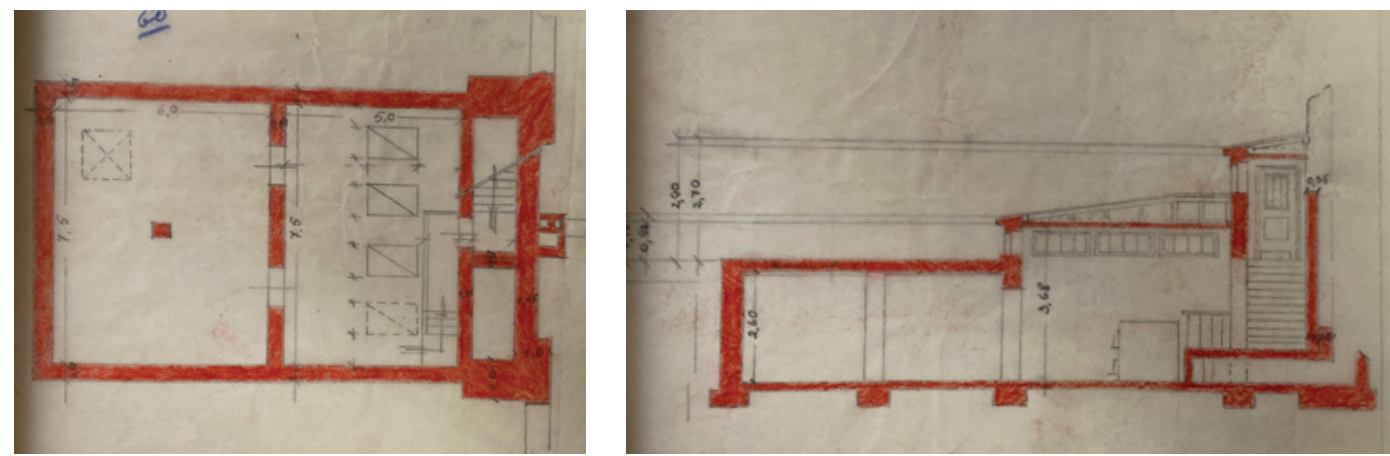

16. attēls. Katla telpas Baldones ielā 7 plāns un griezums (1949). 
1951. gadā nama teritorijā bija tikai divi tenisa laukumi, kas 200 dažādām sporta klasēm atbilstošu tenisistu izaugsmei bija par maz [48].

1960. gadā namam tika iesākts kapitālais remonts, kas ieilga teju divus gadus [49, 50]. Sākot remontu, èkai demontēja veco jumta segumu un iesāka iekštelpu remontu. Iekštelpu remonts jau bija pabeigts, taču jaunais jumta segums vēl nebija uzklāts. Izremontētā ēka vairākus mēnešus bija bez jumta un applūda. 1961. gada nogalē bija paredzēta vērienīga ēkas pārbūve, plānojot tai piebūvēt sporta zāles kompleksu. Projektēšanas uzdevumā bija paredzēts, ka zāli vienlaikus varēs izmantot 24 sportisti. Šis projekts nerealizējās, jo ēkas kapitālais remonts un jumta izbūve prasīja lielus līdzekḷus [51].

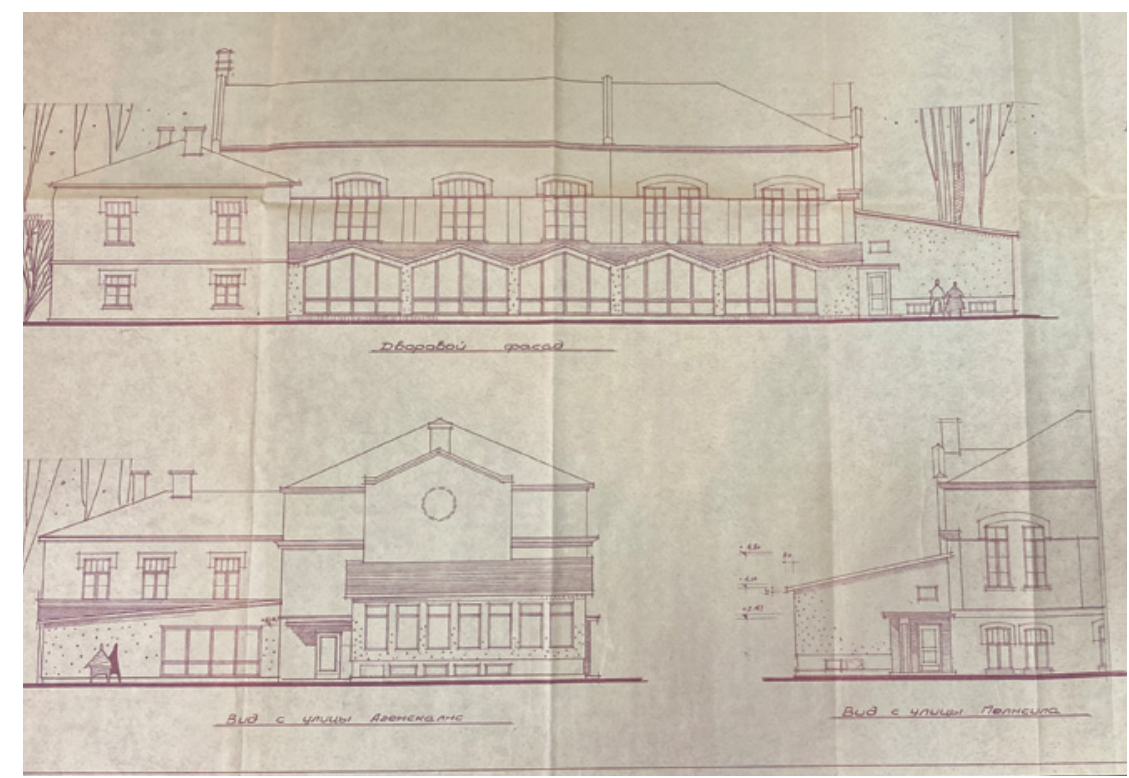

17. attēls. Nama Baldones ielā 7 sporta zāles piebūves (no pagalma puses, Āgenskalna ielas un Melnsila ielas) projekts (1961).

1962. gadā namam atkārtoti tika uzlabota centrālā apkure un mainīta elektroinstalācija [52]. 1964. gadā, atzīmējot sporta biedrības «Daugava» 20 gadu jubileju, labiekārtoja četrus tenisa laukumus, trīs noklājot ar tenisītu, vienu - ar asfaltu, teritoriju apzaḷumoja, iekārtoja vietas skatītājiem [53, 54].

1960. gadu beigās ēkai vētras laikā tika norauts jumts, kuru steidzamības kārtā ar valdības lēmumu atjaunoja, nomainot sapuvušās sijas un paceḷot jumta konstrukciju augstāk, lai spēlējot volejbolu, varētu bumbu pacelt augstāk. 
1971. gadā virs otrā stāva sporta zāles èkai uzcēla vēl vienu stāvu, kurā iekārtoja sporta biedrības «Daugava» direktora kabinetu, metodisko kabinetu un sapulču zāli. Projektā pārplānotas palīgtelpas ēkas pirmajā stāvā, administrācijas telpas otrajā stāvā, izveidota terase ar skatītāju tribīnēm virs kaltu telpas, veikts kaltu telpas remonts. Lielajā tenisa zālē izveidots arī balkons skatītājiem. Visai èkai bija paredzēts kosmētiskais remonts, logu un durvju, kā arī inženierkomunikāciju maiña. Tika izbūvēta pirts ar baseinu ēkas pirmajā stāvā, bija paredzēts pievilkt telefona līniju jaunizveidotajam stāvam [55].
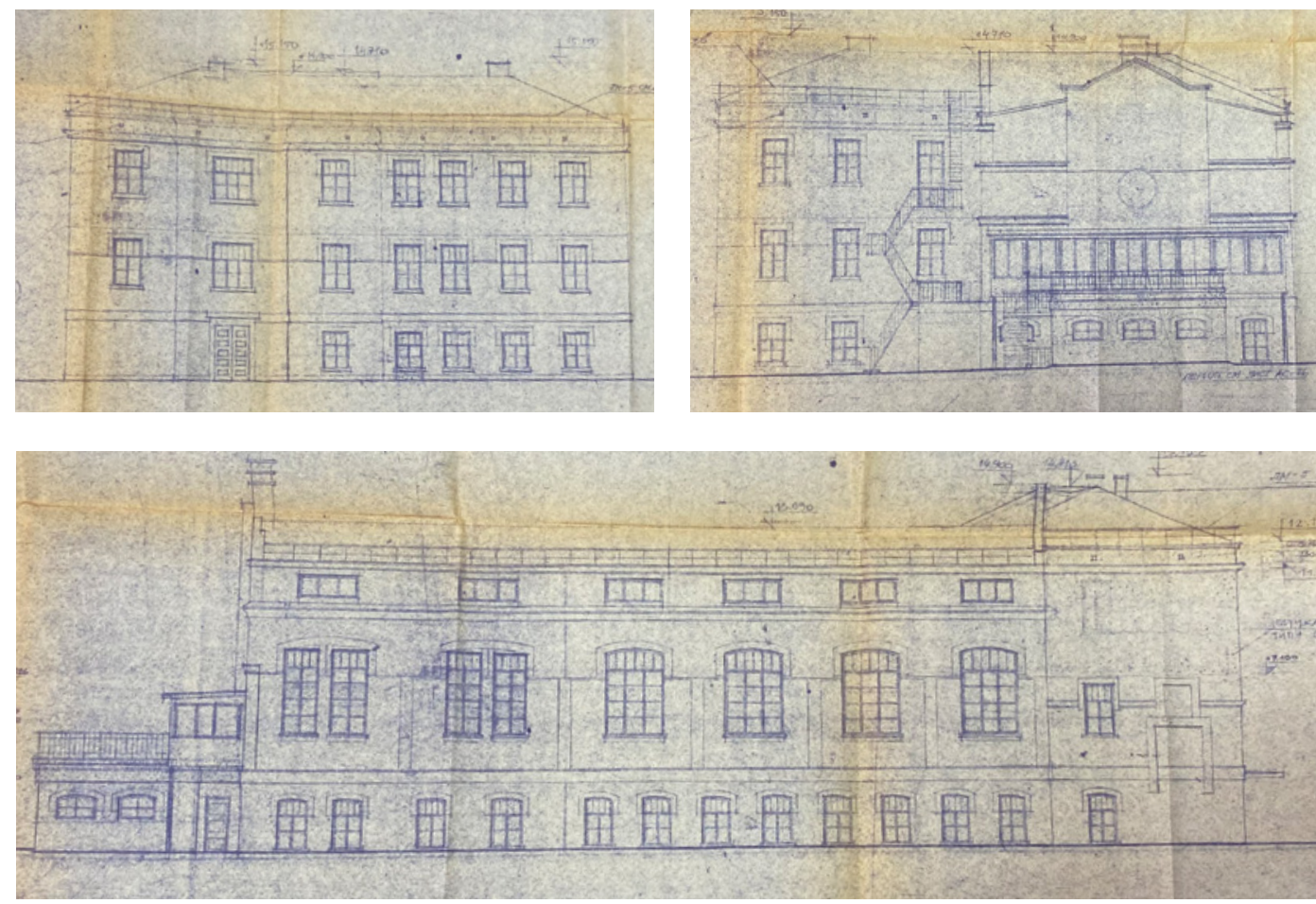

18. attēls. Sporta biedrības «Daugava» nama Baldones ielas, Āgenskalna ielas un Vīlipa ielas fasādes (1971).

Būvinženieres RPI absolventes (1984) Irinas Šatirjonokas vadībā 1998. gadā tika veikta telpu pārplānošana, neparedzot kapitālo sienu un nesošo konstrukciju pārbūvi. Ēkai aizbūvēja puspagraba logus ar $15 \mathrm{~cm}$ padziḷinājumu, veidojot logu imitāciju, pagalma pusē piebūvēja noliktavas, vēlākās garāžas [56]. 


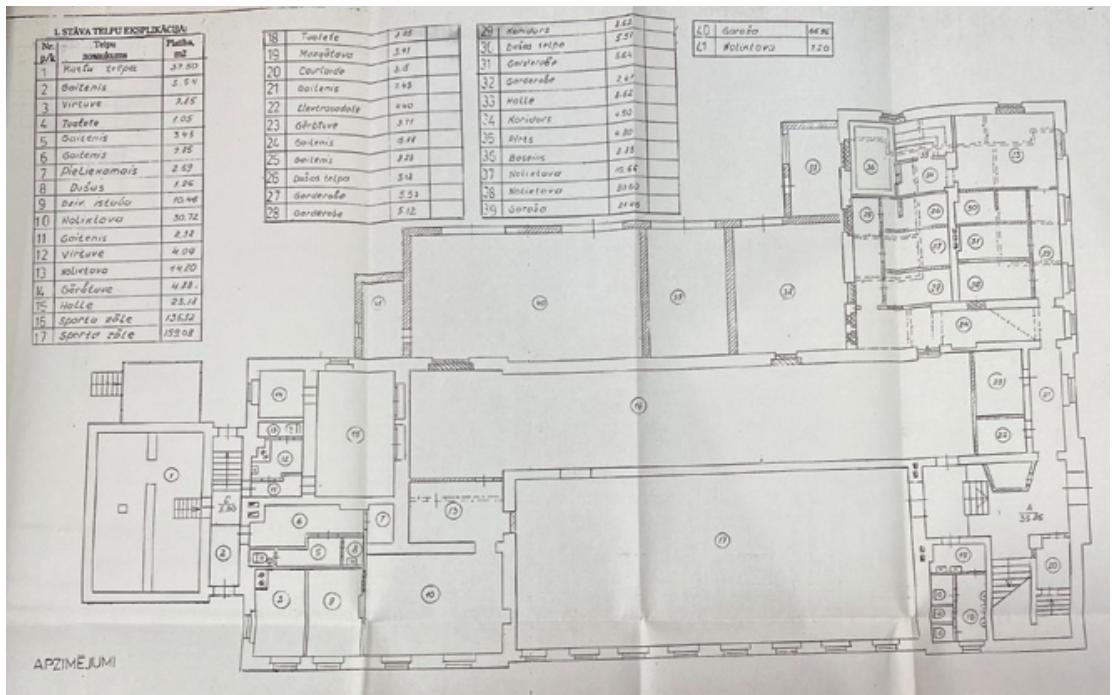

19. attēls. Nama Baldones ielā 7 pirmā stāva plāns ar jaunpiebūvējamām noliktavām (1998).

2003. gadā būvinženiera RPI absolventa (1977) Andreja Ugrimova pārraudzībā tika veikta nama renovāciju un augu pārstādīšana teritorijā [57]. Namu pieslēdza pilsētas ūdensapgādes un kanalizācijas tīklam. Tajā pašā gadā nojauktas noliktavas (garāžas) ēkas pagalma pusē un ierīkotas ārējās kāpnes uz otrā stāva sporta zāli.
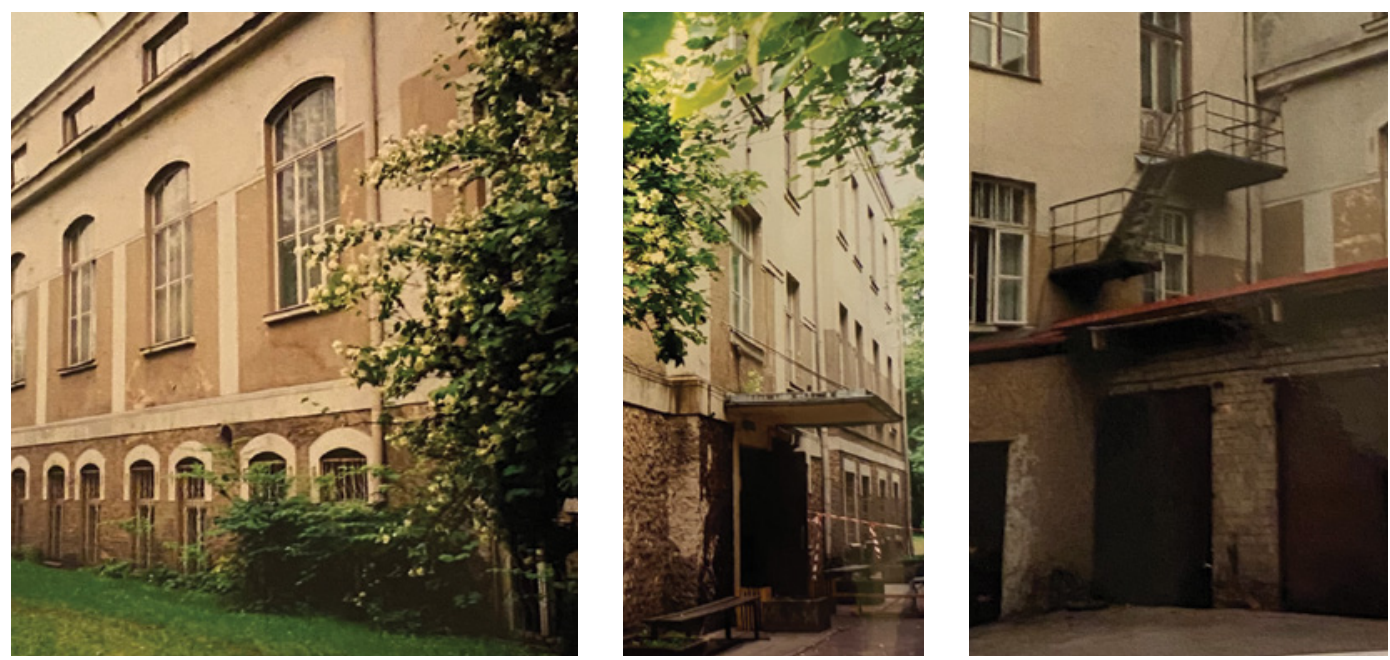

20. attēls. Nama Baldones ielā 7 fotofiksācijas pirms rekonstrukcijas: skats uz Vīlipa ielas fasādi;skats uz Baldones ielas fasādi; skats uz fasādi un noliktavu no pagalma puses (2003). 

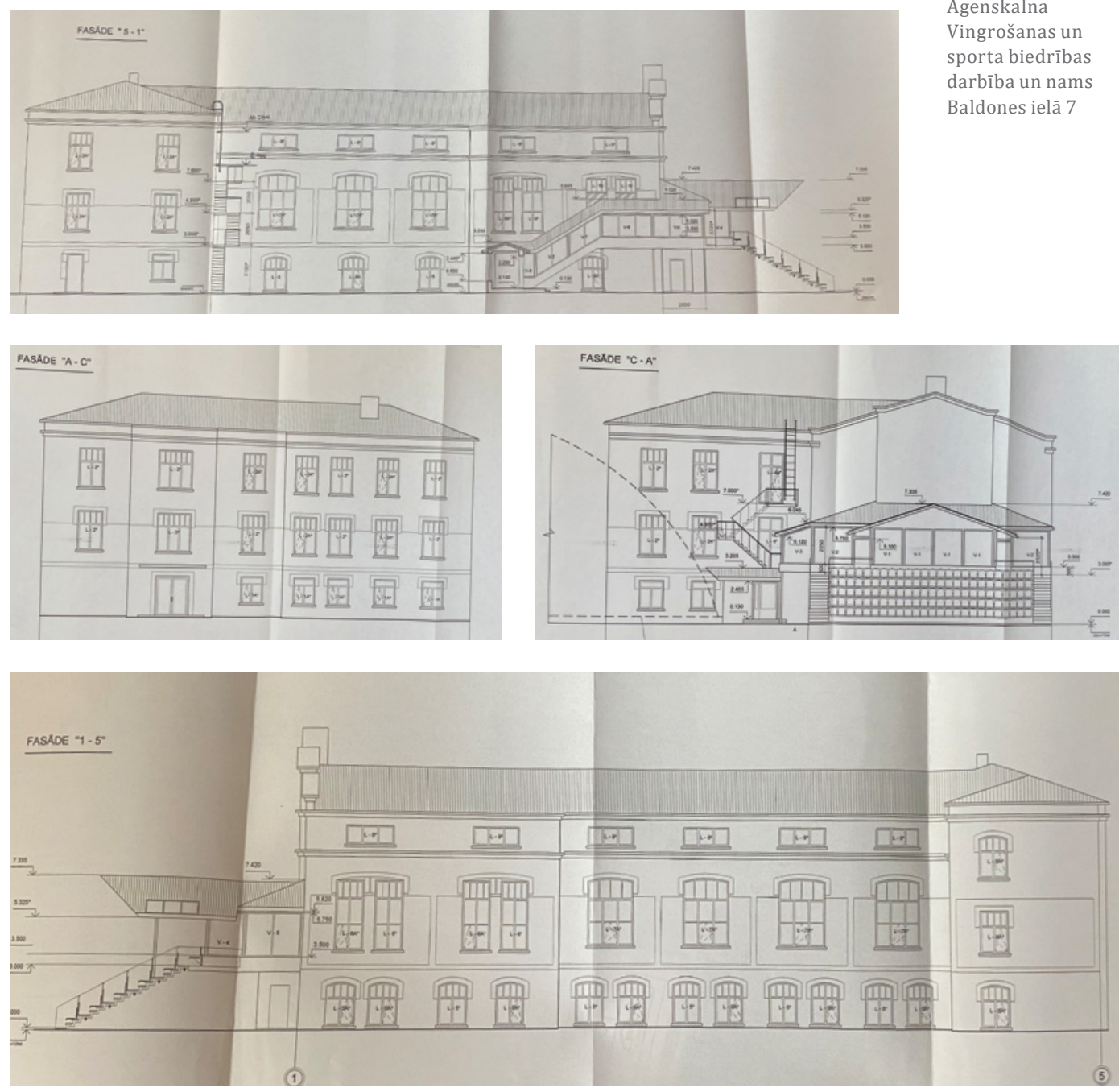

21. attēls. Nama Baldones ielā 7 fasāde pēc projekta izmaināan: no pagalma; no Baldones ielas; no Āgenskalna ielas; no Vīlipa ielas (2003).

2003. gadā arhitektu - RPI absolventa (1982) Igora Kirsanova un RPI absolventa (1979) Viktora Ugrimova vadībā teritorijā izbūvēts jauns slēgts tenisa laukums ar piepūšamo pārsegumu. Tika izbūvēta pāreja no nama uz slēgtajiem kortiem un jaunizveidotajām tribīnēm nama galā [58]. Labiekārtota autostāvvieta teritorijas ZR daḷā. 


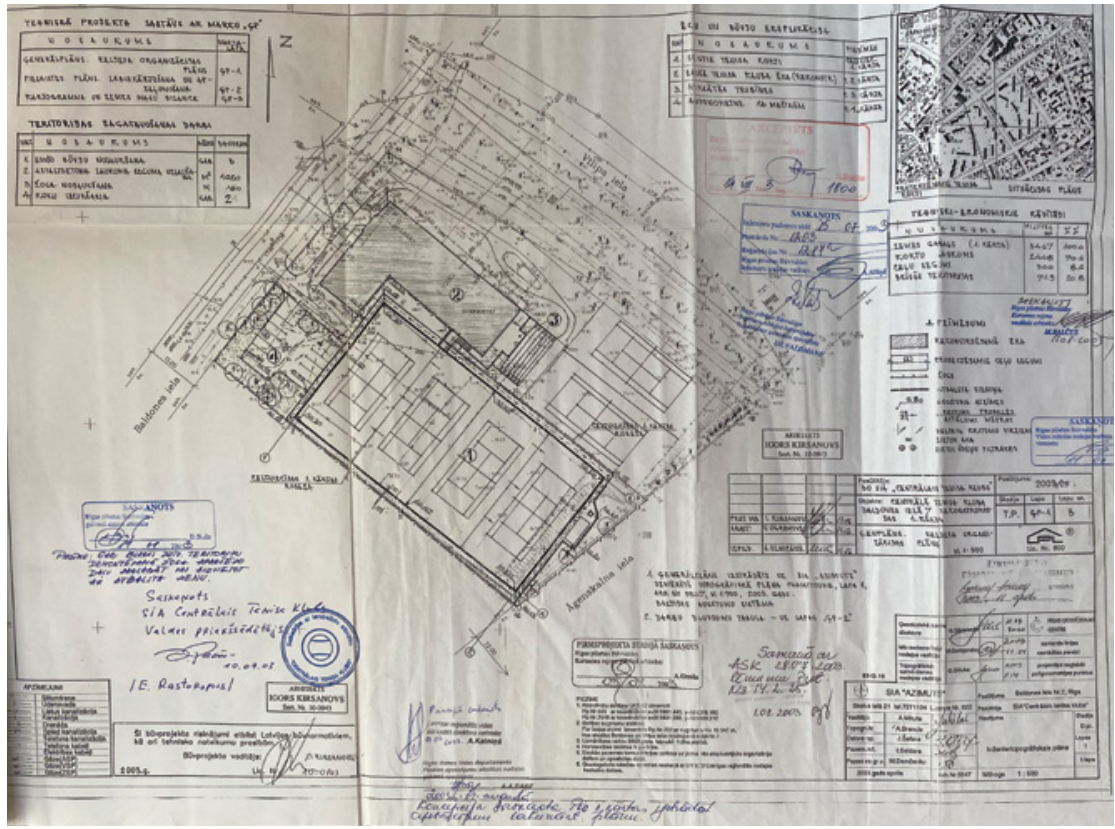

22. attēls. Teritorijas plānojums Baldones ielā 7 (2003).
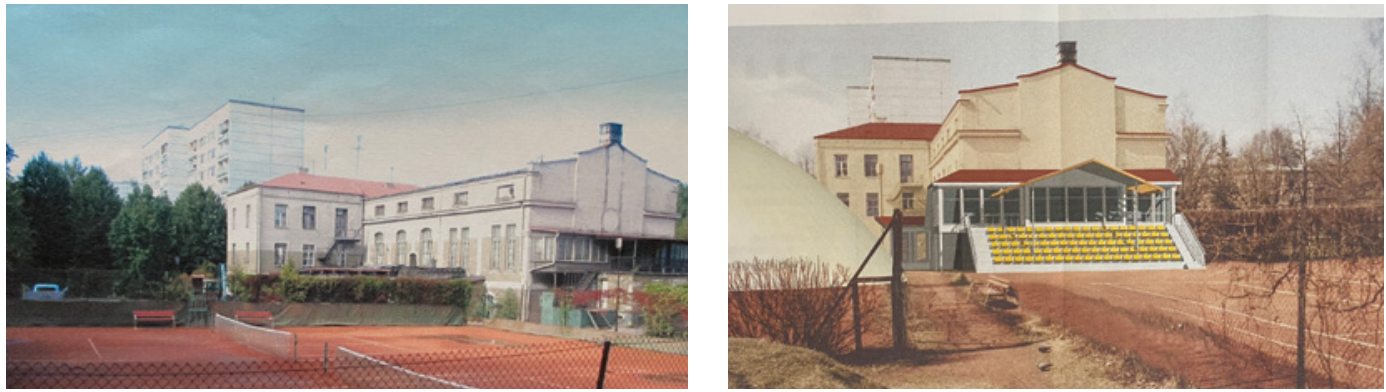

23. attēls. Skats uz ēku Baldones ielā 7 no Āgenskalna ielas, tribīṇu pārbūve (2003).

2009. gadā arhitekts, RTU absolvents (1992) Normunds Babāns izstrādāja kafejnīcas projektu ēkas pirmajā stāvā. Būvdarbus veica uzñēmums SIA «Demo Group» [59].

Nams turpmāk kalpo ne tikai sportam, bet arī izglītībai. 2010. gadā arhitekta Viktora Ugrimova vadībā notika nama otrā un trešā stāva, kā arī pirmā stāva halles pārbūve privātās Krievu kristīgās sākumskolas vajadzībām [60]. Tika izbūvēts platformas tipa ratiṇkrēsla pacēlājs no pirmā uz otro stāvu. Otrajā stāvā pēc pārbūves atrodas: gaitenis, skolēnu gērbtuve un sanitārie mezgli, administrācijas kabineti, divas mācību telpas un rekreācijas halle ar izeju uz ārējām evakuācijas kāpnēm. 
Trešajā stāvā pēc pārbūves atrodas: gaitenis, medicīnas kabinets, skolēnu gērbtuve un sanitārais mezgls, skolotāju sanitārais mezgls, palīgtelpa ar izeju uz jumta, divas mācību telpas un rekreācijas halle ar izeju uz ārējām evakuācijas kāpnēm. Pārbūves gaitā tika nomainīti otrā un trešā stāva logi, kā arī teritorijas žogs gar Baldones ielu. Plānā bija iekḷauta arī fasādes atjaunošana.
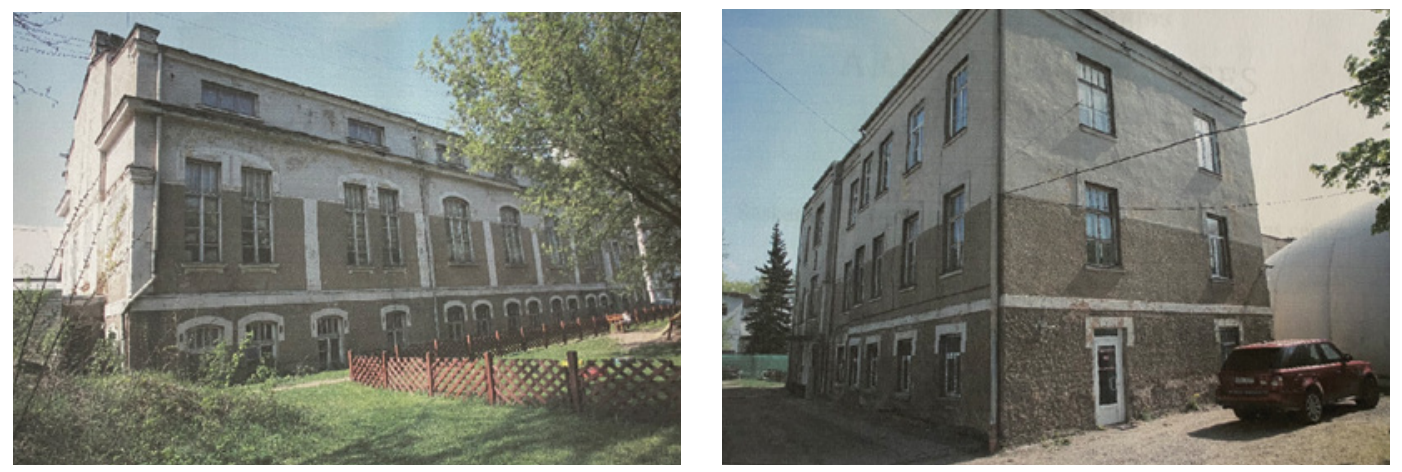

24. attēls. Nams Baldones ielā 7 pirms pārbūves (2009).

2010. gadā ēkā tika izbūvēts lifts. 2011. gadā tika izstrādāts projekts nama bēninu pārbūvei, jumta nomaiṇai un nama fasādes renovācijai, izbūvētajos bēniṇos atvēlot vietu privātās Krievu kristīgās sākumskolas administratīvajām un saimnieciskajām vajadzībām [61]. 2016. gadā projektu īstenoja un nama otrajā stāvā izbūvēja labierīcības personām ar īpašām vajadzībām [62].

25. attēls. Nama Baldones iela 7 renovācijas projekts: fasādes no Vīlipa un Baldones ielas puses (2015).
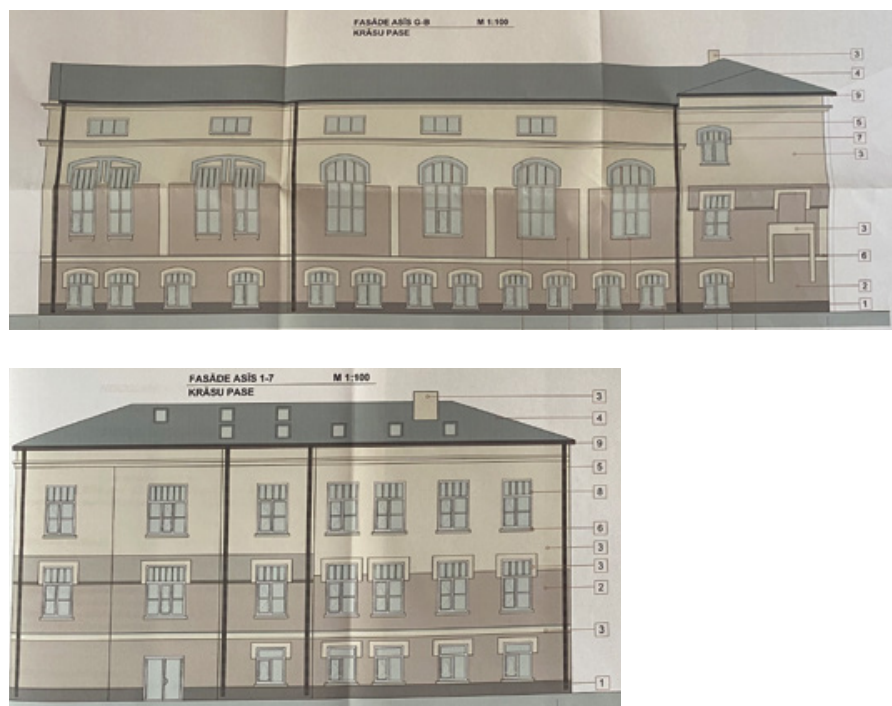


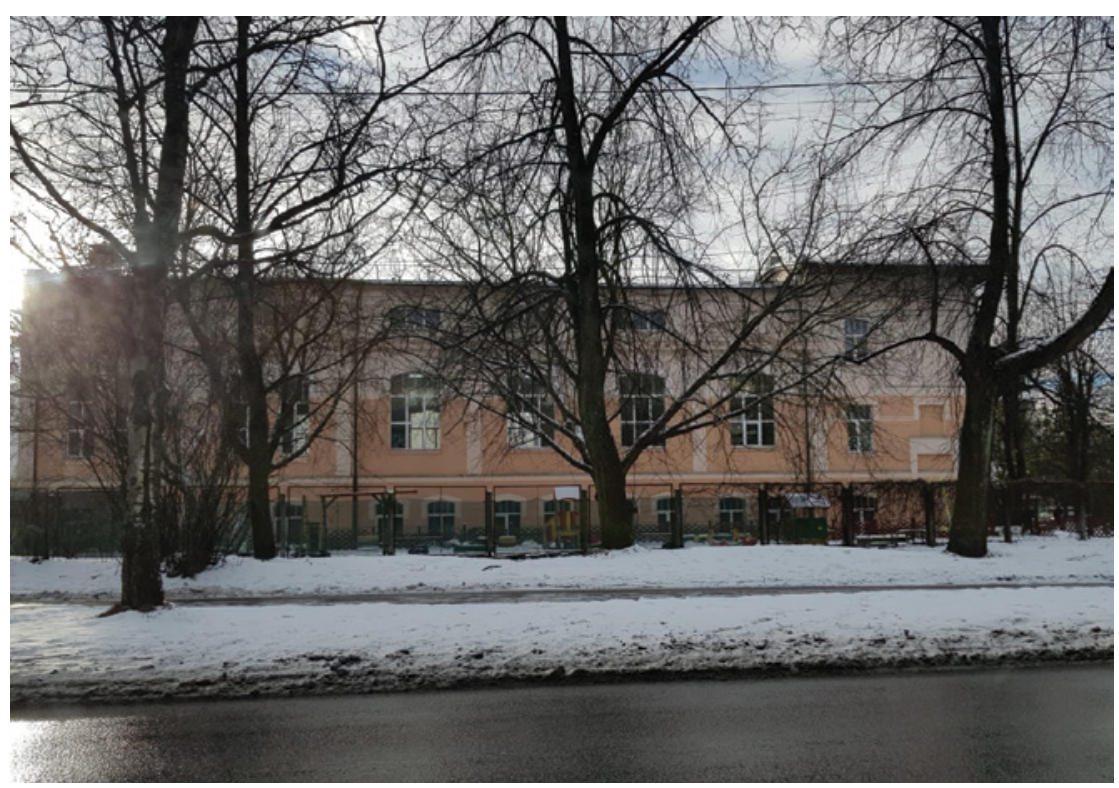

26. attēls. Nams Baldones ielā 7 (2019).

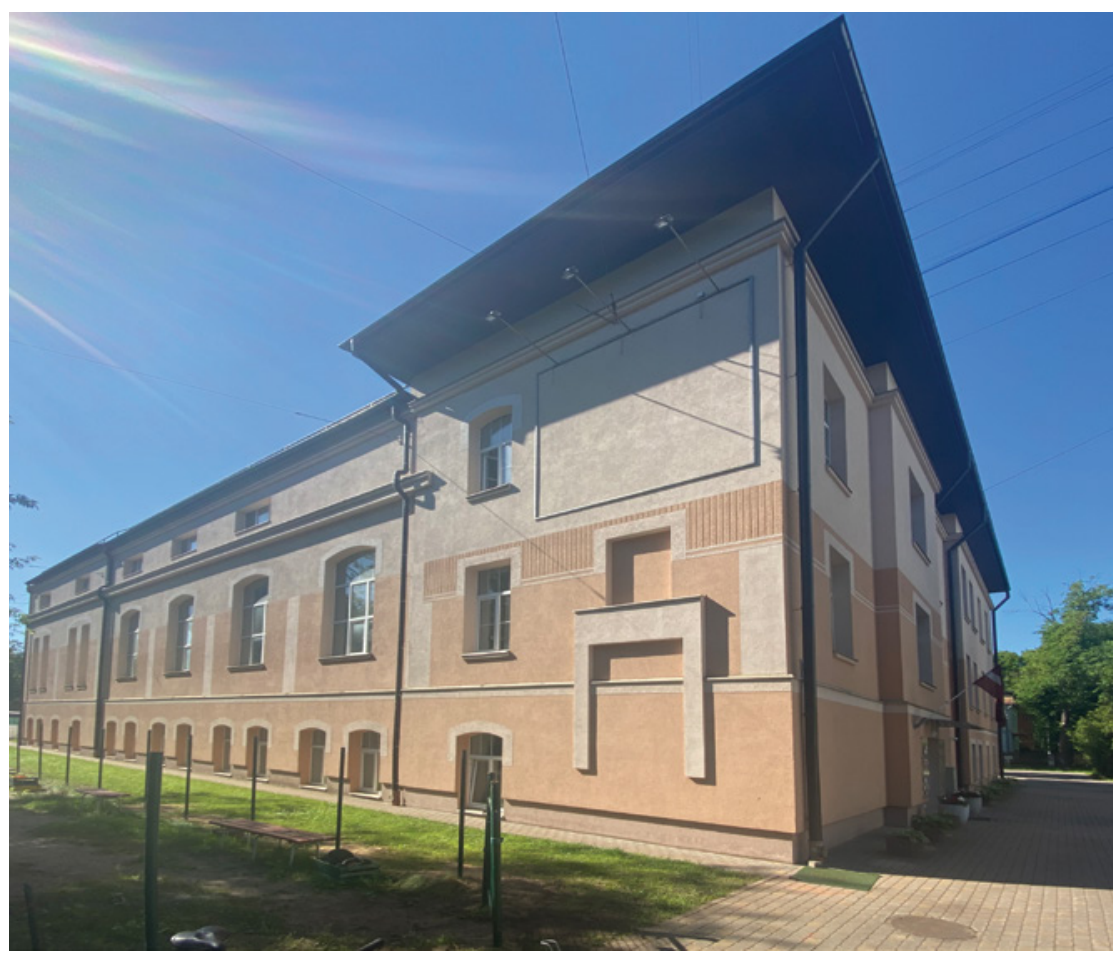

27. attēls. Nams Baldones ielā 7 (2021). 


\section{Nobeigums}

Āgenskalna Vingrošanas un sporta biedrības darbība (1903-1939) ir spilgts vācbaltiešu sporta kultūras paraugs, apliecinot savam laikam modernu domāšanu un izpratni par fizisko kultūru un sportu.

Biedrības nama uzcelšana 1910. gadā pēc arhitekta L. Rīmera projekta ar vingrotavu Baldones ielā 11 mainīja kultūrvidi Āgenskalnā, veicināja sociāli atbildīgas sabiedrības, izglìtības un sporta attīstību Rīgā 20. gadsimta pirmajā pusē.

Starpkaru laikā nama pārbūves un labiekārtošanas darbi (1927, 1935, 1936 un 1937), ko veica arhitekti H. Blaus un A. Laukirbe, pavēra plašas iespējas sabiedriski izglītojošām norisēm un dažādu sporta veidu - tenisa, vingrošanas, volejbola, handbola, tehnisko sporta veidu u. c. - attīstībai.

Otrā pasaules kara gados daḷa biedrības kustamā īpašuma nonāca Poznañā, Polijā, kur neatgriezeniski zuda. Tajā skaitā arī biedrības karogs [4; 62. lp.]. Pēc Otrā pasaules kara kādreizējo ĀVSB īpašumu ar vingrošanas halli sporta, tostarp - tenisa, attīstībai 20. gadsimta sešdesmitajos gados nodrošināja sporta biedrības «Daugava» tenisa klubs ar Bērnu sporta skolu (BSS), kas vēlāk ieguva nosaukumu «Daugavas» Centrālā tenisa kluba sporta skola [63] un kalpoja tenisa, basketbola, volejbola, cinnas sporta u. c. sporta veidu attīstībai.

Kopš 1998. gada Centrālā tenisa kluba (CTK) sporta halle ar slēgtiem un atklātiem tenisa kortiem atradās Latvijas Republikas Izglītības un zinātnes ministrijas valdījumā. 2007. gada 9. jūlijā ministrijas ìpašuma tiesības uz teritoriju ar kopīgo platību 7331 kvadrātmetri Baldones ielā 7 tika izbeigtas sakarā ar īpašuma SIA «Centrālais tenisa klubs» pārdošanu [64].

Kamēr Rīgas domē 2019. gadā turpināja diskutēt ar iedzīvotājiem par izmaiṇām teritoriālajā plānojumā, āgenskalnieši un tenisa sabiedrība vāca parakstus, lai sporta centrs Baldones ielā 7 tiktu saglabāts. 2019. gadā SIA «Centrālais tenisa klubs» (CTK) pasūtīto lokālplānojumu, nolūkā mainīt noteikto zemes lietošanas veidu, lai nepiel̦autu tirdzniecības centra «Lidl» izbūvi [65].

Āgenskalna iedzīvotāju protestu rezultātā pret sporta funkcijas maiṇu CTK, Nacionālā kultūras mantojuma pārvalde 2019. gada 4. septembrī pienēēma lēmumu iekḷaut ĀVSB namu ar tai pieguḷošo teritoriju valsts aizsargājamo kultūras pieminekḷu sarakstā kā vietējas nozīmes vēsturisku notikumu vietu Rīgā [66]. 


\section{ATSAUCES}

[1] Ošinš̌, I. Latvijas un latviešu sportiskie sasniegumi kā kultūras fenomens. Latvieši un Latvija (atb. red. V. Hausmanis, M. Kūle). Rīga: LZA, 2013, IV sēj. 619. lpp.

[2] Rechwenschafts-Bericht des Rigaer Turnvereins fuer das Jubilaeumsjahr 1912. Riga, 1912, S. 18.

[3] Sportvereine. Rigasches Adressbuch 1909. Riga: Adolf Richter, 1909, S. 34, 273., 278.

[4] Alsleben, H. O. Chronik der Familie Alsleben mit Nebenlinien, Teil I. Episoden und Geschichten aus dem Leben der Familie. S. 55-58, 60, 62,65 .

[5] Die Turnabteilung des Hagensberger geselligen Vereins. Rigasche Rundschau, 12. Mai 1903, Nr. 106, S. 5.

[6] Die Turnabteilung des Hagensberger geselligen Vereins. Duena Zeitung, 9. Mai 1903, Nr. 104, S. 5.

[7] Āgenskalna Vingrošanas un sporta biedrības statūti, nama iegādes un citi dokumenti. LNA LVVA 1615. f., 4. apr., 7397. l., 11., 13., 15., 30.,40, 45.-48., 57. lp.

[8] Āgenskalna Vingrošanas un sporta biedrības dokumenti. LNA LVVA 3724. f., 1 apr. 8070. 1., 18., 32, 33, 54. lp.

[9] Wettturnen des Rigaer Turnvereins. Duena Zeitung, 28. Mai 1904, Nr. 118, S. 5 .

[10] Gruendung einer Schuetzengesellschaft in Hagensberg. Duena Zeitung, 25. Oktober 1907, Nr. 248, S. 3.

[11] Der Hagensberger Turn- und Sport-Verein. Baltische Post, 14. Februar 1913, Nr. 38, S. 3.

[12] 25 Jahre Hagensberger Turn- und Sportvereien. Riga am Sonntag, 12. Februar 1928, Nr. 9, S. 6.

[13] Eroeffnung der Paddelsektion. Rigasche Rundschau, 4. Mai 1933, Nr. 100, S. 7.

[14] Āgenskalna Vingrošanas un sporta biedrības darbības, inventāra iegādes un likvidācijas dokumenti. LNA LVVA 3235. f., 5. apr., 22. l, 2.-3., 7. lp.

[15] Āgenskalna Strēlnieku biedrības statūtu reǵistrācija, 1923. gads. LNA LVVA 3724. f., 1. apr., 12178. l., 11., 12., 27. lp.

[16] Āgenskalna Strēlnieku biedrības dokumenti. LNA LVVA 3724 f., 1. apr., 8072. l, 5. lp.

[17] Āgenskalna Slidkalna biedrības likvidācijas dokumenti. LNA LVVA 1799 f., 1 apr. 1 l., 24. lp.

[18] Schwechheimer H., Neumann A. u. a. Hagensberg ohne Wintersport. Rigasche Rundschau, 22 Dezember 1925, Nr. 288, S. 6.

[19] L. Sports. Latvijas Kareivis, 1927. gada 26. novembris, Nr. 266, 3. lpp.

[20] Sport-Propaganda-Woche. Rigasche Rundschau, 28. Februar 1927, Nr. 47, S. 6.

[21] Āgenskalna vingrošanas un sporta b-ba. Sporta Pasaule, 1938. gada 18. novembris, Nr. 568, 9. lpp. 
[22] Basketbolu veicinās arī provincē. Brīvā Zeme, 1936. gada 13. novembrī, Nr. 259, 16. lpp.

[23] Āgenskalna Vingrošanas un sporta biedrība.Valdības Vēstnesis, 1938. gada 3. maijs, Nr. 98, 8. lpp.

[24] Schmied-Kowarcyk, R. «Prases dreier Sportvereine». Auszuge aus den Lebenserinnerungen. Jahrbuch des baltischen Deutschtums 1985. Luneburg, Munchen: Carl-Schirren-Gesellschaft, 1984, S. 118.

[25] Līgums par vācu tautības Latvijas pilsoṇu pārvietošanu uz Vāciju. Valdības Vēstnesis, 1939. gada 30. oktobrī, Nr. 247, 4.-7. lpp.

[26] Likvidētās sporta organizācijas. Fiziskā Kultūra un Sports, 1940. gada 1. janvāris, Nr. 1, 33. lpp.

[27] Āgenskalna Vingrošanas un sporta biedrības likvidācijas lieta. LNA LVVA 3724. f., 1. apr., 8073. l., 1., 11., 44. lp.

[28] Paziñojums. Valdības Vēstnesis, 1939. gada 7. novembris, Nr. 253, 8. lpp.

[29] Āgenskalna Vingrošanas un sporta biedrības dokumenti. LNA LVVA 3724. f., 1. apr., 8071. 1., 1., 22., 24., 27., 31., 33., 34. lp.

[30] Rīt ceḷā dosies otrs vāciešu transports. Brīvā Zeme, 1939. gada 17. oktobris, Nr. 236, 11. lpp.

[31] Āgenskalna Vingrošanas un sporta biedrības nama izmantošanas dokumenti, 1940. g. LNA LVVA 3724. f., 1. apr., 10715. 1., 21. lp.

[32] Rīgas aizsargu pulks izmanto Āgenskalna vingrotavu. Fiziskā Kultūra un Sports, 1940. gada 1. janvāris, Nr. 1, 21. lpp.

[33] Aizsargu vingrotāji izcīnīs Valsts prezidenta balvu. Jaunākās Zingas, 1940. gada 24. aprīlis, Nr. 92, 3. lpp.

[34] Latvijas meistarsacīkstes vingrošanā. Fiziskā Kultūra un Sports, 1940. gada 1. janvāris, Nr. 1, 27. lpp.

[35] Der Hagensberger Turn- und Sport-verein. Duena Zeitung, 4. Dezember 1904, Nr. 277, S. 5.

[36] Āgenskalna Vingrošanas un sporta biedrības likvidācijas dokumenti. LNA LVVA 3724. f.,1. apr., 8076. 1., 2., 3., 5. lp.

[37] Grundsteinlegung. Baltische Post, 20. April 1910, Nr. 88, S. 3.

[38] Album Academicum des Polytechnikums zu Riga, 1862-1912. Riga: Jonck \& Poliewsky, 1912, S. 486.

[39] Āgenskalna Vingrošanas un sporta biedrības ēkas plāns. LNA LVVA 231 f., 6. apr., 7972. 1., 11., 13., 17., 28., 30., 34., 56. lp.

[40] Āgenskalna Vingrošanas un sporta biedrības èkas plāns un citi dokumenti. LNA LVVA 2769. f., 1. apr., 4211. l., 3., 9. lp.

[41] Eine neue Turnhalle in Riga. Rigasche Zeitung, 15. November 1910, Nr. 263, S. 5.

[42] Galīgi piešksirtās rūpniecības iestādes, aug̣̣u dārzi un t. t. Zemes Ierīcības Vēstnesis, 1927. gada 21. oktobris, Nr. 250, 6. lpp.

[43] Rīgā būs jaunas telpas tenisa spēlei. Jaunākās Ziṇas, 1936. gada 8. oktobrī, Nr. 229, 12. lpp.

[44] Vakar beidzās pirmais tenisa turnīrs zem jumta. Sporta Pasaule, 1937. gada 8. februārī, Nr. 352, 4. lpp. 
[45] Ēkas Baldones ielā 7 katlu telpas, centrālapkures, ventilācijas un kanalizācijas izbūve. Rīgas Būvvaldes arhīvs (turpmāk - RBA) 157. grunts, 60. grupa, 9266. lieta.

[46] Odiṇš, Z. Ziema vēl tālu... Padomju Jaunatne, 1949. gada 17. novembris, Nr. 226., 6. lpp.

[47] Gatavoties ziemai, paaugstināt sporta techniskos rezultatus. Padomju Jaunatne, 1950. gada 30. novembris, Nr. 234, 1. lpp.

[48] Lūsis, J. Vissavienības meistarsacīkstes tenisā. Padomju Jaunatne, 1951. gada 17. oktobris, Nr. 204, 4. lpp.

[49] Mežavilks, Z., Stumbris, E., Liepiṇš, I. Tumši traipi. Sports, 1960. gada 15. decembris, 4. lpp.

[50] Austriṇš, A., Pḷavnieks, G. Nams iet bojā. Sports, 1962. gada 20. decembris, Nr. 148., 3. Ipp.

[51] Sporta zāles piebūve namam Baldones ielā 7. RBA 156., 157. grunts, 60. grupa, 9135. lieta, 1. lp.

[52] Strobs, J. Spēka zari. Padomju Jaunatne, 1962. gada 26. augusts, Nr. 168, 3. lpp.

[53] Stadionu atklās svētdien. Rīgas Balss, 1964. gada 8. maijs, Nr. 108, 4. Ipp

[54] Zilgalvis, L. Kur vējš dzenāja smiltis. Sports, 1964. gada 14. maijs, Nr. 56, 2. lpp.

[55] Centrālā tenisa kluba ēkas Baldones ielā rekonstrukcija, 1. kārta. RBA, 156. grunts, 60. grupa, bez numura.

[56] Centrālā tenisa kluba iekšējā plānojuma izmaiṇu izpildprojekts. RBA, 157. grunts, 60. grupa, 62207. lieta.

[57] Centrālā tenisa kluba rekonstrukcija, 2. kārta, RBA, 157. grunts, 60. grupa, 83733. lieta.

[58] Centrālā tenisa kluba rekonstrukcija, 2. kārta, RBA, 157. grunts, 60. grupa, 82991. lieta, 4. lp.

[59] Centrālā tenisa kluba Baldones ielā 7 rekonstrukcijas projekta izmaiṇu projekts, RBA, 157. grunts, 60. grupa, 82997. lieta.

[60] Ēkas Baldones ielā 7 2. un 3. stāva rekonstrukcija privātās Krievu kristīgās skolas vajadzībām, RBA, 157. grunts, 60. grupa, 105923. lieta.

[61] Ēkas Baldones ielā 7, Rīgā bēniṇu stāva rekonstrukcija, RBA, 157. grunts, 60. grupa, 110924. lieta.

[62] Ēkas Baldones ielā 7, Rīgā bēninuu stāva rekonstrukcija (legalizācija), Būvprojekts, RBA, 157. grunts, 60. grupa, 133517. lieta.

[63] Fizkultūrieša kalendārs 1961.-1988. gadiem. Rīga: LVI, 1961-1988.

[64] Rīgas pilsētas Vidzemes priekšpilsētas tiesas Zemesgrāmatu nodaḷa. Rīgas pilsētas zemesgrāmatas nodalījums Nr. 31084. Kadastra numurs: 0100060 0157, adrese: Baldones iela 7, Rīga.

[65] Āgenskalna iedzīvotāji nobremzē «Lidl» veikalu Baldones ielas tenisa kortu vietā [tiešsaiste]. https://jauns.lv/raksts/zinas/318705agenskalna-iedzivotaji-nobremze-lidl-veikalu-baldones-ielas-tenisakortu-vieta [skatīts: 30.06.2021].

[66] Nacionālās kultūras mantojuma pārvaldes lēmums Nr. 08-09.2/4230 2019. gada 4. septembrī. 


\section{ILUSTRĀCIJU AVOTI}

1. attēls. Āgenskalna Vingrošanas un sporta biedrības ēkas plāns un citi dokumenti. LNA LVVA 2769, 1. apr., 4211. l., 23. lp.

2. attēls. Āgenskalna Vingrošanas un sporta biedrības dokumenti. LNA LVVA 3724. f., 1 apr. 8070. l., 18. lp.

3. attēls. Alsleben, H. O. Chronik der Familie Alsleben mit Nebenlinien, Teil I. Episoden und Geschichten aus dem Leben der Familie.

4. attēls. Babetes Alslebenes kundzes /Frau Babett Alsleben/privātais arhīvs.

5. attēls. Alsleben, H. O. Chronik der Familie Alsleben mit Nebenlinien, Teil I.

Episoden und Geschichten aus dem Leben der Familie.

6. attēls. Āgenskalna Vingrošanas un sporta biedrības ēkas plāns un citi

dokumenti. LNA LVVA 2769. f., 1 apr., 4211. l., 3. lp.

7. attēls. Raimunda Kovarčika pase. LNA LVVA 2996. f., 10. apr., 38508. 1., 5. lp.

8. attēls. Āgenskalna Vingrošanas un sporta biedrības ēkas plāns. LNA LVVA 231. f., 6. apr., 7972. 1. lp.

9. attēls. Āgenskalna Vingrošanas un sporta biedrības ēkas plāns. LNA LVVA

231. f., 6. apr., 7972. 1. lp.

10. attēls. Āgenskalna Vingrošanas un sporta biedrības ēkas plāns. LNA LVVA 231. f., 6. apr., 7972. l., 10. lp.

11. attēls. Āgenskalna Vingrošanas un sporta biedrības statūti, nama iegādes un citi dokumenti. LNA LVVA 1615. f., 4. apr., 7397. l., 57. lp.

12. attēls. Āgenskalna Vingrošanas un sporta biedrības ēkas plāns. LVA LVVA 231. f., 6. apr., 7972 l., 10. lp.

13. attēls. Āgenskalna Vingrošanas un sporta biedrības ēkas plāns. LNA LVVA 231 f., 6 apr., 7972 1., 1. lp.

14. attēls. Āgenskalna Vingrošanas un sporta biedrības dokumenti. LNA LVVA 3724. f., 1. apr., 8076. l., 1. lp.

15. attēls. Āgenskalna Vingrošanas un sporta biedrības dokumenti. LNA LVVA 3724. f., 1. apr., 8076. 1., 1. lp.

16. attēls. Ēkas Baldones ielā 7 katlu telpas, centrālapkures, ventilācijas un kanalizācijas izbūve. RBA 157. grunts, 60. grupa, 9266. lieta, 59., 60. lp.

17. attēls. Sporta zāles piebūve namam Baldones ielā 7. RBA 156., 157. grunts, 60. grupa, 9135. lieta.

18. attēls. Centrālā tenisa kluba ēkas Baldones ielā rekonstrukcija, 1. kārta. RBA 156. grunts, 60. grupa, bez numura.

19. attēls. Centrālā tenisa kluba iekšējā plānojuma izmainuu izpildprojekts. RBA

157. grunts, 60. grupa, 62207. lieta.

20. attēls. Centrālā tenisa kluba rekonstrukcija, 2. kārta. RBA 157. grunts, 60. grupa, 83733. lieta.

21. attēls. Centrālā tenisa kluba rekonstrukcija, 2. kārta. RBA 157. grunts, 60. grupa, 83733. lieta.

22. attēls. Centrālā tenisa kluba rekonstrukcija, 2. kārta. RBA 157. grunts, 60. grupa, 82991. lieta, 4. lp.
Rita Apine

Āgenskalna

Vingrošanas un

sporta biedrības

darbība un nams

Baldones ielā 7 
23. attēls. Centrālā tenisa kluba rekonstrukcija, 2. kārta. RBA 157. grunts, 60. grupa, 83733. lieta.

24. attēls. Ēkas Baldones ielā 7 2. un 3. stāva rekonstrukcija privātās Krievu kristīgās skolas vajadzībām. RBA 157. grunts, 60. grupa, 105923. lieta

25. attēls. Ēkas Baldones ielā 7, Rīgā bēninuu stāva rekonstrukcija (legalizācija), Būvniecības iecere. RBA 157. grunts, 60. grupa, 133514. lieta.

26. attēls. Foto - Lauma Jaunzeme.

27. attēls. Foto - Ilze Gudro.

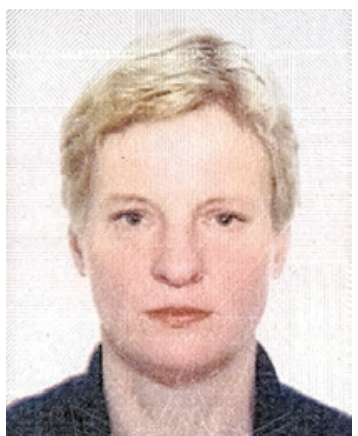

RITA APINE, Mg. paed., Leading Researcher at the Latvian Sport Museum. Co-author of a number of publications - a collection of books and articles on Latvian sports and the most outstanding personalities. Research interests - history of Latvian sports and research of athletes' curricula vitae.

Address: 9 Alksnāja Street, Riga, LV-1050, Latvia Phone: +371 67225127

E-mail: rita.apine@sportamuzejs.lv

Rita Apine

\section{Activities of Āgenskalns Gymnastics and Sports Society and its Headquarters at 7 Baldones Street}

$\bar{A}$ genskalns Gymnastics and Sports Society was one of the largest and best-known Baltic-German sports organizations in the first half of the 20th century. Sports enthusiasts of various professions, including engineers, participated in the activities of this society. The house built by the Society in 1910 at 7 Baldones Street, Riga, which has been rebuilt several times, played an important role in the sports life. The research presents comprehensive documentary evidence about the Society until the repatriation of the Baltic-Germans in 1939 and the history of its headquarters building. Using the documents and press materials from the Latvian State Historical Archive (LSHA) of the National Archives of Latvia (NAL), archive documents of the Riga Construction Board, as well as the collection of the Latvian Sports Museum, previously unknown facts have been revealed.

Keywords: Āgenskalns Gymnastics and Sports Society, 7 Baldones Street, architects: Leopolds Rīmers, Haralds Blaus, Alfrēds Laukirbe. 